Western University

Scholarship@Western

Civil and Environmental Engineering

Civil and Environmental Engineering

Publications

Department

2017

Shape Memory Alloy Reinforced Concrete Frames Vulnerable to

Strong Vertical Excitations

\author{
M A. Elfeki \\ Western University \\ Maged A. Youssef \\ Western University, youssef@uwo.ca
}

Follow this and additional works at: https://ir.lib.uwo.ca/civilpub

Part of the Structural Engineering Commons

Citation of this paper:

Elfeki, M A. and Youssef, Maged A., "Shape Memory Alloy Reinforced Concrete Frames Vulnerable to Strong Vertical Excitations" (2017). Civil and Environmental Engineering Publications. 194.

https://ir.lib.uwo.ca/civilpub/194 


\title{
SHAPE MEMORY ALLOY REINFORCED CONCRETE FRAMES VULNERABLE TO STRONG VERTICAL EXCITATIONS
}

\author{
M.A. ELFEKI ${ }^{1}$, M.A. YOUSSEF ${ }^{2, *}$ \\ ${ }^{1}$ Alexandria University, Department of Civil Engineering, Cairo, Egypt \\ ${ }^{2}$ Western University, Department of Civil and Environmental Engineering, London, ON N6A 5B9, Canada
}

\begin{abstract}
Reinforced concrete (RC) framed buildings dissipate the seismic energy through yielding of the reinforcing bars. This yielding jeopardizes the serviceability of these buildings as it results in residual lateral deformations. Superelastic Shape Memory Alloys (SMAs) can recover inelastic strains by stress removal. This paper extends previous research by the authors that optimized the use of SMA bars in RC frames considering the horizontal seismic excitation by addressing the effect of the vertical seismic excitation. A steel RC six-storey building designed according to current seismic standards is considered as case study. Five different earthquake records with strong vertical components are selected for the nonlinear dynamic analysis. The results were used to evaluate the effect of the vertical excitation on the optimum locations of SMA bars.
\end{abstract}

Keywords: seismic damage; seismic residual deformations; shape memory alloy; superelasticity; moment frame; reinforced concrete, vertical seismic component

\footnotetext{
* Corresponding author: $\quad$ Tel.: +1 (519) 661-2111x 88661; fax: +1 (519) 661-3779. E-mail address: youssef@uwo.ca
} 


\section{Introduction}

The vertical component of a ground motion is usually considered the weakest component. Thus, structures designed using the horizontal component are assumed to have a large factor of safety for the vertical component [Mwafy, 2001]. Although the vertical-to-horizontal peak ground acceleration $(\mathrm{V} / \mathrm{H})$ for near fault earthquakes can be higher than unity [Ambraseys and Simpson, 1996], the most commonly used value for $\mathrm{V} / \mathrm{H}$ is $2 / 3$, which was proposed by Newmark et al. [1973]. V/H is mostly affected by two main factors: the epicentral distance and the earthquake magnitude. $\mathrm{V} / \mathrm{H}$ ratio is found to exceed one for distances less than $5 \mathrm{~km}$ from the ground motion source and to be higher than $2 / 3$ for distances up to $40 \mathrm{~km}$ [Abrahamson and Litehiser, 1989; Bozorgnia et al., 1995]. It has also been observed that $\mathrm{V} / \mathrm{H}$ ratio is related to the magnitude of an earthquake [Elnashai and Papazoglou, 1997; Collier and Elnashai, 2001]. The damaging effect of vertical excitation is affected by the interaction of the horizontal and the vertical peaks [Elnashai and Papazoglou, 1997 and Collier and Elnashai, 2001].

The high vertical seismic components result in a significant fluctuation in the axial forces of the columns [Papadopoulou, 1989; Papaleontiou and Roesset, 1993; Broderick and Elnashai, 1994; Georgantzis, 1995]. This fluctuation reduces the ductility of the columns [Abdelkareem and Machida, 2000] and has resulted in significant structural damage following the 1986 Kalamata earthquake $(\mathrm{V} / \mathrm{H}=0.81), 1994$ Northridge earthquake $(\mathrm{V} / \mathrm{H}=1.79)$, and 1995 Kope earthquake $(\mathrm{V} / \mathrm{H}=1.21)$ [Papazoglou and Elnashai, 1996]. A strong vertical excitation is also expected to significantly increase the vertical response of long beams [Papazoglou and Elnashai, 1996]. For concrete buildings, earthquake energy is dissipated through yielding of steel reinforcing bars. The level of seismic damage depends on the frequency content and magnitude of the earthquake as well as details of the structure. Superelastic Shape Memory Alloys (SMAs) are a class of 
material that can recover from large inelastic strains upon removal of the applied stresses. This results in several unique characteristics, including high damping and re-centring capabilities. These outstanding characteristics attracted researchers and designers to use SMA to enhance the post-earthquake serviceability and reduce residual lateral deformations. SMAs are used as passive, semi-active, and active components to reduce damage caused by earthquakes [Song et al., 2006]. Due to their high cost, it is not until recently that they found their way as reinforcing bars in Reinforced Concrete (RC) structures. Sakai et al. [2003], Saiidi and Wang [2006], Youssef et al. [2008], and Alam et al. [2008] have studied analytically or experimentally the effect of using SMA bars on the seismic performance of reinforced concrete elements (beam, column, or beam-column joint). Alam et al. [2009] has examined the effect of using SMA bars on the seismic performance of an eight-storey building. Youssef and Elfeki [2012] have defined the required locations of SMA bars in a typical RC frame to optimize its performance for horizontal seismic excitations in terms of damage scheme and seismic residual deformations.

Over the last 10 years, the cost of SMA has been significantly reduced; from more than US $\$ 1000 / \mathrm{kg}$ to below US $\$ 150 / \mathrm{kg}$ [Alam et al., 2007]. This raises the need for studies to assess the effect of using SMA reinforcing bars on the seismic performance of RC framed structures. Recommendations for designing SMA framed structures are also needed.

The objective of this paper is to examine the potential of using SMA bars in RC structures vulnerable to seismic events with a strong vertical seismic component. Time history analyses are performed for regular steel RC frame using five earthquakes having significant vertical components. A comparative study between the seismic performances of the frame when considering and ignoring the vertical seismic component is presented. The frame is then redesigned using SMA bars in the identified critical locations of the steel RC frame. Seven 
different arrangements for the SMA bars are selected resulting in seven different frames. Nonlinear dynamic analyses are conducted using the same records for the seven frames to identify the frame having the best seismic performance. A comprehensive comparative study is then conducted between the seismic performance of the steel RC frame and the selected SMA $\mathrm{RC}$ frame in terms of lateral capacity, roof drift, maximum inter-story drift (MID), maximum residual inter-story drift (MRID), and the earthquake intensity causing collapse.

\section{Steel RC Frame Characteristics and Modeling}

The symmetric six-storey RC office building (Frame 1) designed by Youssef and Elfeki [2012] is considered in this paper as a case study. The building dimensions, layout and design details are presented by Youssef and Elfeki [2012].

The finite element program SeismoStruct [Seismosoft, 2008] is selected to be used in this study. The program is capable of representing spread of inelasticity within the member length using the fiber analysis approach. Concrete is represented using the model of Martinez-Rueda and Elnashai [1997], while the steel is modeled using the bilinear kinematic strain hardening model [Monti and Nuti, 1992]. The SMA is modeled using the model of Auricchio et al. [1997], which is available in SeismoStruct. To account for the effect of the vertical excitation on the beams, the floor masses are lumped at the end of each beam element rather than at the beam-column joints (each beam is modeled using six beam elements). SeismoStruct was previously validated for dynamic loading up to 1.0g (Alam et al. 2009, Youssef and Elfeki 2012) and quasi-static cyclic loading up to failure (Alam et al. 2008).

Local yielding of elements is defined when the tensile strain in the longitudinal reinforcement reaches the yield strain ( 0.002 for steel and 0.007 for SMA). Concrete crushing is assumed to 
occur when the confined concrete strain causes the stirrups to reach their fracture strength as proposed by Paulay and Priestley [1992].

\subsection{Dynamic Analysis of the Steel RC Frame}

Eigen value analysis is performed to determine both the horizontal and the vertical periods of the

frame. The horizontal and vertical fundamental periods of vibrations are found equal to 0.501 second and 0.075 second, respectively. The first four vertical mode shapes are shown in Figure 1. It can be observed that the beams are expected to experience higher vertical deformations due to the vertical excitation.

The following sections presents a comparison between the results of the dynamic analyses considering only the horizontal seismic component [Youssef and Elfeki, 2012] and that obtained in this paper in terms of the roof drift ratio, damage schemes, Sa causing collapse, and the values of MID and MRID at collapse.

\subsubsection{Selection of Ground Motion Records}

Five earthquakes with effective vertical components are selected. The characteristics of the chosen records are presented in Table 1. As the destructive effect of the vertical excitation is highly affected by the $\mathrm{V} / \mathrm{H}$ ratio and the earthquake magnitude [Abrahamson and Litehiser, 1989 and Papazoglou and Elnashai, 1996], the records are selected such that their Magnitude and V/H ratio are higher than 5.7 and 0.6 , respectively. These records are also covering a wide range of ground motion frequencies represented by the ratio between the peak ground acceleration and the peak ground velocity $(\mathrm{A} / \mathrm{v}$ ratio). $\mathrm{Sa}(\mathrm{T} 1,5 \%)$ is used to scale the records. Every earthquake has three components, two in the horizontal direction (HL) and one in the vertical direction (VL). 
The spectral accelerations for the two horizontal components are drawn and compared at the fundamental period of the moment frame $\left(T_{1}=0.501\right)$. The one with the higher value is selected for the analysis. Each of the chosen horizontal records is scaled to different levels of $\mathrm{Sa}(0.501$, 5\%). The vertical component is scaled using the same scaling factor to keep the $\mathrm{V} / \mathrm{H}$ ratio constant. Both horizontal and vertical components are then used in the dynamic analysis. Frame collapse is assumed when the concrete of four columns in the same storey reaches the crushing strain.

\subsubsection{Damage Schemes}

The damage schemes at collapse are shown in Figure 2. It can be observed that: (1) collapse of the building occurs due to crushing of the lower ends of the first-storey columns, (2) yielding is initiated in most of the beams and columns, (3) all the beams sustains yielding at their mid-spans due to the high vertical deformations caused by the vertical component, (4) crushing is observed at the beams of the upper three floors and in the outer columns of the sixth and/or the fifth stories in cases of Northridge, Whittier, and Loma Prieta earthquakes. By comparing the obtained damage schemes with those presented by Youssef and Elfeki [2012], the significant damaging effect of the vertical seismic component is clearly observed. The vertical components of the records have significantly increased the number of the yielded sections to include the ends of all beams and columns and the mid-spans of some beams. They have also increased the vertical deformations of the beams, which led to crushing of a number of beams and columns at the top stories. The frame has collapsed at a lower Sa when the vertical component is considered.

\subsubsection{Drift values}


Figure 3 presents the relationship between the base shear and the mean roof drift for the sixstorey building. Up to about $1.4 \%$ roof drift, the frame behaviour is not affected by the vertical component. The vertical excitation has reduced the load and drift capacities of the frame. The over-strength factors are equal to 2.08 and 1.96 when the vertical excitation is ignored and accounted for, respectively.

Table 2 presents the values of MID and MRID at collapse and identify the critical storey. The following observations can be made by examining the table: (1) the values of MID at collapse are varying between $2.96 \%$ and $4.83 \%$, thus the 4\% MID suggested by FEMA 273 [1997] represents the average value of the calculated MIDs, (2) the MRID collapse limits are varying between $1.12 \%$ and $2.40 \%$, thus the 3\% MRID suggested by FEMA 273 [1997] is unconservative, (3) the storey experiencing the MID is not necessarily the same one experiencing the MRID, and (4) while no crushing is observed at any of the second storey columns, the MID and/or the MRID are observed at this storey. Point 4 clearly indicates that using a single value of MID or MRID is not an accurate method to estimate the position of local damage.

Table 3 shows a comparison between the values of Sa, MID, and MRID at collapse when the vertical component is ignored and accounted for. The vertical seismic component has significantly reduced the three values ( $\mathrm{Sa}, \mathrm{MID}$ and MRID). Thus, the frame is reaching its collapse state at lower levels of Sa.

\section{Design of SMA RC Frames}

To enhance the seismic performance of the steel RC frame, SMA bars are utilized at a number of the identified critical sections. The optimum SMA locations that are identified by Youssef and Elfeki [2012] might not provide the same benefits because of the vertical seismic excitation. 
Thus, seven design alternatives for positioning the SMA bars are considered based on the conducted dynamic analyses: [1] SMA bars at the ends of all beams to address the observed yielding (Frame 2), [2] SMA bars at the bottom ends of the first storey columns to address the observed crushing (Frame 3), [3] SMA bars at the ends of the fourth floor beams (Frame 4) to address the crushing and yielding observed at those beams, [4] SMA bars at the ends of the fifth floor beams (Frame 5) to address the crushing and yielding observed at those beams, [5] SMA bars at the ends of the sixth floor beams (Frame 6) as they are the most affected beams by the vertical seismic excitation, [6] SMA bars at the ends of the first floor beams to study the effect of using SMA in the beams adjacent to the critical columns (Frame 7), [7] SMA bars at the ends

of the sixth and first floor beams (Frame 8). Figure 4 shows the locations of the SMA RC sections in the seven considered alternatives. These frames are subjected to dynamic analyses using the same records causing failure to the steel RC frame.

The SMA RC sections are designed based on the method proposed by Elbahy et al. [2009]. The assumptions made while designing the SMA RC sections and estimating the plastic hinge length are presented in details by Youssef and Elfeki [2012].

\subsection{Dynamic Analysis for the SMA RC Frames}

Each SMA RC frame is subjected to dynamic analyses using the same five earthquake records used for the steel RC frame. The horizontal and vertical components of each record are scaled to the intensity causing collapse of the steel RC frame. In the following sections, the seismic performance of those frames is evaluated in terms of the experienced damage and drift values.

\subsubsection{Damage Schemes}


The damage schemes of the seven frames are illustrated in Figures 5 to 11. The figures show that: (1) most of the sections at the ends of the columns and the beams, and at mid-spans of the beams have reached yielding, (2) crushing is observed at the beams of the higher stories in case of Northridge, Whittier and Loma Prieta earthquakes due to excessive vertical excitation demand imposed by the vertical excitation.

The damage schemes for Frame 2, Figure 5, show that: (1) no crushing can be observed at the beam sections, (2) in case of Whittier record, crushing is concentrated at the third storey where five column sections are crushed and the frame can be considered at the collapse state, (3) for the remaining earthquakes, column crushing is not concentrated at one floor and the frame can withstand higher seismic intensities.

The damage schemes for Frame 3, Figure 6, show that: (1) crushing can be observed at the outer columns of the fifth and/or the sixth stories in case of Northridge, Whittier and Loma Prieta earthquakes, (2) the frame can be considered at collapse state in case of Whittier and Loma Prieta records, (3) the frame can withstand higher seismic intensities in case of Imperial Valley, Northridge and San Fernando ground motion records.

The damage schemes for Frame 4, Figure 7, show that: (1) column crushing is mainly concentrated at the first storey level, (2) column crushing is observed in the outer columns of the higher stories in case of Whittier and Loma Prieta records, and (3) the frame can withstand higher seismic intensities in case of Northridge record and is considered at the collapse state for other records.

The damage schemes of Frame 5, Figure 8, show that: (1) using SMA at the fifth floor beams has reduced the number of crushed beams and columns in case of Whittier and Loma Prieta records, (2) in case of Northridge and Loma Prieta, the frame can tolerate minor increase in the 
earthquake intensity before collapse, (3) in case of Imperial valley, Whittier, and San Fernando, the frame can be considered at failure state.

The damage schemes of Frame 6, Figure 9, show that: (1) this SMA configuration has significant effect on the enhancing the local damage at the higher stories, (2) the frame can be considered at the collapse state in case of Imperial Valley and Whittier records and can withstand higher seismic intensities for the other records.

The damage schemes of Frame 7, Figure 10, shows that: (1) the maximum number of crushed columns in one storey level is observed in case of Loma Prieta earthquake where three columns crushed at the first storey levels, (2) Only one column at the first storey has sustained crushing in cases of Whittier, Imperial Valley, and Northridge, (2) Frame 6 can tolerate higher values of Sa for all of the used records, (3) this configuration of SMA bars does not enhance the local damage at higher stories as clearly reflected by the large number of crushed beams and outer columns in cases of Northridge, Whittier, and Loma Prieta records.

The damage schemes for Frame 8, Figure 11, show that: (1) crushing is observed at only one of the first storey columns in cases of Imperial Valley and Whittier records, (2) no column crushing is observed in cases of Northridge and San Fernando records, (3) this alternative has reduced number of crushed columns and beams at the higher stories in cases of Northridge, Whittier, and Loma Prieta earthquakes, and (4) the frame can sustain higher seismic intensities. It can be concluded that the arrangement of SMA bars in this frame have reduced the damage in the first storey columns because of the SMA bars at the beams adjacent to the critical columns. It has also reduced the damage experienced by the upper floors because of the SMA bars at the sixth floor beams. 


\subsubsection{Evaluating the Frames According to Drift Values}

The values of the MID and the MRID for the SMA RC frames are illustrated in Table 4. The average values are presented in Figure 12 as well. The figure shows that while the steel RC frame has the lowest average MID (4.17\%), Frame 2 (SMA used at 48 sections) has the highest average MID (5.57\%). All the other alternatives have relatively similar values (varying from $4.38 \%$ to $4.72 \%$ ). Table 4 also presents the percentage difference between the average values of MID and MRID of the SMA RC frames and those of the Steel RC frame. The maximum increase in the average MID demand is $33.69 \%$ for Frame 2 where SMA bars are used at 48 sections. For the other frames, this increase is ranging between $4.99 \%$ for Frame 4 with SMA at 8 sections (at the end of all the fourth floor beams) and $8.93 \%$ for Frame 6 with SMA used at 5 sections (at the bottom ends of the first storey columns). The main reason for the increase in the MID values is because of the low value of the modulus of elasticity of SMA, which is almost one third of the steel modulus of elasticity.

The average values of MRID demands, Figure 12, show that the location of SMA bars greatly affects the MRID demand. Table 4 shows that the percentage decrease in the average values of MRID has reached $61.78 \%, 58.50 \%, 37.87 \%$, and $21.45 \%$ for Frame 2, 8, 7 and 3, respectively. On the contrary, using SMA in Frames 4, 5, and 6 has led to increase in the average MRID demands $(26.61 \%, 30.95 \%$ and $35.76 \%$, respectively). These observations can show that the MRID demands in SMA RC frames are very sensitive to the location of SMA bars. Improper use of SMA reinforcement may lead to excessive permanent deformations.

From the damage schemes and the drift values, it is clear that using a reasonable amount of SMAs at the right locations leads to lower level of damage, minor increase in the MID, and high reduction in the MRID as compared to a steel RC frame. Frame 8 is considered to have the best 
seismic performance as it has the best damage scheme during dynamic analyses, minor increase in MID demands, and high reduction in the MRID. This frame can also tolerate earthquakes with higher intensities.

In the following sections, a comprehensive comparison between the seismic performance of Frame 8 and the steel RC frame will be conducted using Incremental Dynamic Analyses (IDA).

\section{Steel RC Frame versus SMA RC Frame}

In this section, a comprehensive comparative study between the seismic performance of steel RC frame and that of Frame 8 is conducted. The frames are subjected to IDA using the same records used in previous sections up to collapse.

\subsection{IDA Results}

The results of the IDA are presented in Figure 13a, 13c, and 13e for Frame 1 and in Figure 13b, 13d and 13f for Frame 8. The comparison between Figures 13a and 13b show that using SMA in Frame 8 has minor effect on the maximum base shear demand. The average increase in the maximum base shear demand of Frame 8 is almost $7.0 \%$. The figures also show that using SMA bars in the frame has led to better ductility as the roof drift ratio reaches $3.32 \%$ in some cases while it does not exceed $2.05 \%$ in case of the steel frame. By comparing Figures $13 \mathrm{c}$ and $13 \mathrm{e}$ for Frame 1 with Figures $13 \mathrm{~d}$ and $13 \mathrm{f}$ for Frame 8, it can be noticed that at the low levels of $\mathrm{Sa}$, the two buildings experienced almost the same values of MID and MRID. By increasing the Sa level, Frame 8 experiences slightly higher values of MID than those of Frame 1. On the contrary to this phenomenon, the MRIDs of the SMA frame are significantly lower than those of the steel frame, especially at high levels of Sa (Figures 13e and 13f). Figures 14a 
and $14 \mathrm{~b}$ show that, both the steel and the SMA frames have almost the same values of MID and MRID in case of Imperial Valley and up to Sa equals $0.7 \mathrm{~g}$. At Sa values higher than $0.7 \mathrm{~g}$, the MID ratios of the SMA frame are slightly increased than those of the steel frame. The maximum difference is at $\mathrm{Sa}$ of $1.15 \mathrm{~g}$, where the MID of Frames 1 and 8 are $4.80 \%$ and $6.00 \%$, respectively. Figure $14 \mathrm{~b}$ shows that re-centring effect of the SMA is very significant. At high levels of Sa, the MRID for Frames 1 and 8 have reached $3.20 \%$ and $1.40 \%$, respectively.

\subsection{Spectral Accelerations Causing Collapse}

By comparing the damage scheme of the two frames, Figures 2 and 11, it can be noticed that the Sa causing collapse for the steel RC frame is not defining failure for the SMA RC frame. Extra non-linear dynamic analyses for the SMA frame are performed using the same records scaled to higher levels of Sa. For each earthquake record, the damage scheme of the SMA frame at collapse is presented in Figure 15. Table 5 shows the Sa intensities causing collapse. The table also presents the values of the MID and the MRID at collapse. Figure 15 shows that collapse is due to concentration of crushing in the first storey columns. It can be observed from Tables 2 and 5 that the Sa causing collapse to the SMA frame are much higher than those causing collapse to the steel RC frame. The increase in the earthquake intensity has reached a value of $25.5 \%$ in case of Northridge. Table 5 also shows that at collapse, the MID are varying from $4.19 \%$ to $7.38 \%$, while the MRID are varying from $1.00 \%$ to $2.00 \%$. By comparing these values to those obtained for the steel RC frame (Table 2), it can be concluded that the SMA frame is more ductile than the steel frame as it reaches higher values of MIDs without collapse during dynamic analyses and with less permanent drifts. Table 5 shows that both the MID and the MRID cannot be used to predict the location of the local damage. 


\section{Seismic Performance of Frame 8 in Case of Horizontal Earthquakes}

The previous sections discussed the effect of SMA bars in Frame 8 in case of earthquakes having horizontal and vertical components. As RC frames may be subjected to a horizontal excitation associated with a negligible vertical component, the seismic performance of Frame 8 needs to be evaluated for such a case.

Nonlinear dynamic analyses using only the horizontal components of the previously selected five ground motion records are conducted for Frames 1 and 8. Each earthquake record is scaled to different $\mathrm{Sa}(0.501$ second, 5\%) levels. Figures 16 and 17 show the damage scheme of Frames 1 and 8, respectively, at Sa causing collapse of the steel RC frame. The figures show that Frame 8 can tolerate higher seismic intensities than Frame 1. At the Sa causing collapse of Frame 1, Figure 18 shows the average values of MIDs and MRIDs for the two frames. It can be noticed that using SMA bars causes slight increase in MID (6.43\%) and a significant decrease in the average MRID demands (70.01\%).

Further investigation is carried out to compare Frame 8 with the best SMA frame selected by Youssef and Elfeki [2012], which has SMA bars at the critical beams (the fourth floor beams) and the critical columns (first storey columns). The damage schemes are almost identical for the two frames in cases of Whittier, San Fernando, and Loma Prieta earthquakes. In cases of Imperial Valley and Northridge, there are minor differences. The average values of MIDs and MRIDs for the two frames have minor differences. While the average values of MIDs for Youssef and Elfeki [2012] Frame and Frame 8 have reached 5.68\% and 5.53\%, respectively, the average values of MRID are only $0.69 \%$ and $0.96 \%$, respectively. Frame 8 is proved to provide 
superior seismic performance when the vertical seismic excitation is ignored or taken into account.

\section{SUMMARY AND CONCLUSIONS}

This paper aims at evaluating the seismic performance of SMA RC frames that are vulnerable to vertical seismic excitations. Because of the high cost of SMA bars and their low stiffness, the paper also aims at defining the minimum amount of SMA bars that can be used to enhance the frame seismic behaviour in terms of residual permanent deformations and damage scheme.

A six-storey steel-RC frame located in highly seismic zone is considered as case study. The frame is subjected to nonlinear dynamic analysis using five different earthquake records with significant vertical components. The seismic performance of this frame is compared with its seismic performance when only the horizontal seismic component is considered. The comparison is conducted in terms of roof drift, Sa causing collapse, damage schemes, and values of MID and MRID at collapse. After defining the position of the critical sections, the building is redesigned using seven different configurations for the SMA bars. Those seven buildings are subjected to nonlinear dynamic analysis using the five earthquake records scaled to the same predefined Sa causing collapse of the Steel RC Frame. The frame experiencing the least damage is selected. A comparative study is then carried out between the seismic performance of the steel RC frame and the selected SMA RC frame.

The dynamic analyses that have been conducted on the steel RC frame have led to the following conclusions.

1) Crushing of the first storey columns is causing collapse of the frame. 
2) The vertical component of the records caused high vertical deformations in all of the beams. These vertical deformations caused yielding at the mid-span of almost all beams and crushing at the ends of the beams at the top floors.

3) The MID representing the collapse varies between $2.96 \%$ and $4.83 \%$ showing that the $4 \%$ MID suggested by FEMA 273 [1997] is close to the obtained average value. On the contrary, the 3\% MRID suggested by FEMA 273 [1997] is unconservative as the MRID at failure obtained from the analyses varied between $1.12 \%$ and $2.40 \%$.

4) The analyses for the steel RC frame confirmed that using single value of MID or MRID cannot estimate the position of local damage.

Results of dynamic analyses for the seven SMA Frames have led to the following conclusions.

1) Using SMA bars in the beams of the top floors leads to local enhancement of the seismic performance of these floors.

2) Using SMA bars in the critical columns does not provide any benefit.

3) Using SMA bars at the ends of all beams significantly improves the damage scheme but leads to reduction in the building global stiffness and significant cost increase.

4) Using SMA bars at the ends of beams in the floor adjacent to the critical columns (first floor beams) has led to very good results under the effect of all the earthquake records. This is due to the re-centring effect of the SMA material which has minimized the residual drifts of the beams and consequently the demand on the adjacent columns.

5) The best arrangement of SMA bars is found to be a combination of using them at the critical sections of the beams ( $6^{\text {th }}$ floor beams) and at the ends of the beams adjacent to the critical columns (1st floor beams). This arrangement (Frame 8) gives best seismic performance 
represented by low number of crushed columns, minor increase in the MIDs, and significant decrease in MRIDs.

6) While the MID values are affected by the amount of SMA bars, the damage and the MRIDs are sensitive to the location of these bars.

Using IDA, the seismic performances of Frame 1 and 8 have been compared in terms of Lateral capacity, roof drift, MID, MRID, and the Sa level causing collapse. The results have shown that:

1) SMA bars have minor effect on the lateral capacity.

2) The SMA frame experiences slightly higher values of MID than those of the steel RC frame.

3) Using SMA bars have significantly reduced the MRID of the frame.

4) The re-centring effect of SMA allows the frame to undergo larger drifts with lower permanent drifts. This has led to reduction in the number of crushed columns.

5) The SMA frame is able to sustain higher earthquake intensities.

The seismic performance of Frames 1 and Frame 8 are also examined using only the horizontal seismic components. The comparison between the performance of the two frames shows that Frame 8 is also superior for this case. It can tolerate higher Sa intensities without collapse, experiences minor increase in MID demands, and results in significant reduction in the MRIDs. Thus, using this innovative material in the beams adjacent to the critical columns and in the critical beams leads to significant improvements in the seismic performance of RC frames. 


\subsection{References}

Abdelkareem, K. H. and Machida, A. [2000] "Effects of vertical motion of failure mode and ductility of RC bridge piers," Proc. of the 12th World Conference on Earthquake Engineering, New Zealand Society for Earthquake Engineering, Auckland, New Zealand, Paper No. 0463.

Abrahamson, N. A. and Litehiser, J. J. [1989] "Attenuation of vertical peak acceleration," Bulletin of Seismological society of America 79(3): 549-580.

Alam, M.S., Youssef, M.A. and Nehdi, M. [2007] "Utilizing shape memory alloys to enhance the performance and safety of civil infrastructure: a review,' Canadian Journal of Civil Engineering 34(9): 1075-1086.

Alam, M.S., Youssef, M.A. and Nehdi, M., [2008] "Analytical prediction of the seismic behaviour of superelastic shape memory alloy reinforced concrete elements," Engineering Structures 30(12): 3399-3411.

Alam, M.S., Nehdi, M. and Youssef, M.A. [2009] "Seismic Performance of Concrete Frame Structures Reinforced with Superelastic Shape Memory Alloys," Smart Structures and Systems 5(5): 565-585.

Ambraseys, N.N. and Simpson, K.A. [1996] "Prediction of vertical response spectra in Europe," Earthquake Engineering and Structural Dynamics 25(4): 401-412.

Auricchio, F., Taylor, R.L. and Lubliner, J. [1997] "Shape-memory alloys: macromodelling and numerical simulations of the superelastic behaviour," Computer Methods in Applied Mechanics and Engineering 146(3-4): 281-312.

Bozorgnia, Y., Niazi, M. and Campbell, K. W. [1995] "Characteristics of free-field vertical ground motion during the Northridge earthquake," Journal of Earthquake Spectra 11(4): 515525.

Broderick, B. M. and Elnashai, A. S. [1994] "Seismic resistance of composite beam-columns in multi-storey structures, Part 2: Analytical model and discussion of results," Construction Steel Research 30(3): 231-258.

Collier, C.J. and Elnashai, A.S. [2001] "A procedure for combining vertical and horizontal seismic action effects," Journal of Earthquake Engineering 5(4): 521-539.

Elbahy, Y.I., Youssef, M.A. and Nehdi, M. [2009] "Stress Block Parameters for Concrete Flexural Members Reinforced with Shape Memory Alloys," Materials and Structures, 42(10): 1335-1351.

Elnashai, A.S. and Papazoglou, A.J. [1997] "Procedure and spectra for analysis of RC structures subjected to strong vertical earthquake loads," Journal of Earthquake Engineering 1(1): 121-155

FEMA 273 [1997] "NEHRP Guidelines for the Seismic Rehabilitation of Buildings," Federal Emergency Management Agency, Washington, DC, USA.

Georgantzis, M.M. [1995] "Effect of vertical motion on behaviour factors," M.Sc. Dissertation, ESEE, Imperial College, London, UK.

Martinez-Rueda, JE. and Elnashai, A.S. [1997] "Confined concrete model under cyclic load," Materials and Structures 30(197): 139-147. 
Monti, G., and Nuti, C. [1992] "Nonlinear cyclic behaviour of reinforcing bars including buckling," Journal of Structural Engineering, ASCE 118(12): 3268-3284.

Mwafy, A.M. [2001] "Seismic performance of code-designed RC buildings," Ph.D. thesis, Imperial college, London, UK.

Newmark, N. M., Blume, J. A. and Kapur, K. K. [1973] "Seismic design spectra for nuclear power plants," Journal of the Power Division, ASCE 99(2): 287-303.

Papadopoulou, O. [1989] "The effect of vertical excitation on reinforced concrete multi-storey structures," M.Sc. Dissertation, ESEE Section, Imperial College, London, UK.

Papaleontiou, C. and Roesset, J.M. [1993] "Effect of vertical acceleration on seismic response of frames," Structural Dynamics-EURODYN'93 conference, Balkema, Rotterdam, The Netherlands, pp. 19-26.

Papazoglou, A. J. and Elnashai, A. S. [1996] "Analytical and field evidence of the damaging effect of vertical earthquake ground motion," Earthquake Engineering and Structural dynamics 25(10): 1109-1137.

Paulay, T. and Priestley, M.J.N. [1992] "Seismic design of reinforced concrete and masonry buildings," John Wiley \& Sons, New York, NY, USA.

Saiidi, MS. and Wang, H. [2006] "Exploratory study of seismic response of concrete columns with shape memory alloys reinforcement," ACI Structural Journal 103(3): 435-442.

Sakai, Y., Kitagawa, Y., Fukuta, T. and Iiba, M., [2003] "Experimental study on enhancement of self-restoration of concrete beams using SMA wire," Proceedings of SPIE Vol. 5057, Smart Structures and Materials, Smart Systems and Nondestructive Evaluation for Civil Infrastructures, pp. $178-186$.

SeismoSoft [2008] "SeismoStruct - A computer program for static and dynamic nonlinear analysis of framed structures," Available from URL: http://www.seismosoft.com.

Song, G., Ma, N. and Li, H.N. [2006] "Applications of shape memory alloys in civil structures," Journal of Engineering Structures 28(9): 1266-1274.

Youssef, M.A., Alam, M.S. and Nehdi M. [2008] "Experimental investigation on the seismic behaviour of beam-column joints reinforced with superelastic shape memory alloys," Journal of Earthquake Engineering 12(7): 1205-1222.

Youssef M.A. and Elfeki M.A. [2012], "Seismic Performance of Concrete Frames Reinforced with Superelastic Shape Memory Alloys," Smart Structures and Systems, 9(4): 313-333. 
Table 1 : Earthquake records

\begin{tabular}{|c|l|c|c|c|c|c|c|}
\hline \multirow{2}{*}{ Earthquake } & Date & \multirow{2}{*}{$\begin{array}{c}\text { Magnitude } \\
\text { (Ms) }\end{array}$} & Station & \multicolumn{2}{|c|}{ PGA (g) } & V/H & A/v \\
\cline { 1 - 1 } $\begin{array}{c}\text { Northridge } \\
\text { (USA) }\end{array}$ & $17 / 1 / 94$ & 6.7 & $\begin{array}{c}\text { Arleta- } \\
\text { Nordhoff }\end{array}$ & 0.34 & 0.55 & 1.62 & Inter. \\
\hline $\begin{array}{c}\text { Imperial } \\
\text { Valley } \\
\text { (USA) }\end{array}$ & $15 / 10 / 79$ & 6.9 & $\begin{array}{c}\text { El Centro } \\
\text { Array \#6 } \\
\text { (E06) }\end{array}$ & 0.44 & 1.65 & 3.75 & Low \\
\hline $\begin{array}{c}\text { Loma Prieta } \\
\text { (USA) }\end{array}$ & $18 / 10 / 89$ & 7.1 & $\begin{array}{c}\text { Capitola } \\
\text { (CAP) }\end{array}$ & 0.53 & 0.54 & 1.02 & High \\
\hline $\begin{array}{c}\text { Whittier } \\
\text { (USA) }\end{array}$ & $1 / 10 / 87$ & 5.7 & $\begin{array}{c}\text { Whittier } \\
\text { Dam }\end{array}$ & 0.32 & 0.51 & 1.59 & High \\
\hline $\begin{array}{c}\text { San } \\
\text { Fernando }\end{array}$ & $9 / 2 / 71$ & 6.6 & $\begin{array}{c}\text { Pacoima } \\
\text { Dam }\end{array}$ & 1.23 & 0.7 & 0.57 & Inter. \\
\hline
\end{tabular}

Table 2: MIDs and MRIDs of the Steel RC frame at failure

\begin{tabular}{|l|c|c|c|c|}
\hline \multirow{2}{*}{\multicolumn{1}{c|}{ Earthquake record }} & \multicolumn{2}{c|}{ Storey experiencing MID } & \multicolumn{2}{c|}{ Storey experiencing MRID } \\
\cline { 2 - 5 } & Storey No. & MID (\%) & Storey No. & MRID (\%) \\
\hline Northridge $(2.47 \mathrm{~g})$ & $2^{\text {nd }}$ & 4.80 & $2^{\text {nd }}$ & 1.67 \\
\hline Imperial Valley $(1.10 \mathrm{~g})$ & $2^{\text {nd }}$ & 3.93 & $2^{\text {nd }}$ & 2.40 \\
\hline Loma Prieta $(3.80 \mathrm{~g})$ & $1^{\text {st }}$ & 2.96 & $2^{\text {nd }}$ & 1.12 \\
\hline Whittier $(4.75 \mathrm{~g})$ & $1^{\text {st }}$ & 4.83 & $1^{\text {st }}$ & 1.67 \\
\hline San Fernando $(6.50 \mathrm{~g})$ & $2^{\text {nd }}$ & 4.32 & $1^{\text {st }}$ & 1.67 \\
\hline
\end{tabular}

Table 3: Effect of vertical excitation on the performance of the steel RC frame at failure

\begin{tabular}{|l|c|c|c|c|c|c|}
\hline \multirow{2}{*}{ Earthquake } & \multicolumn{3}{c|}{ Horizontal } & \multicolumn{3}{c|}{ Horizontal + vertical } \\
\cline { 2 - 7 } & Sa (g) & MID (\%) & MRID (\%) & Sa (g) & MID (\%) & MRID (\%) \\
\hline Northridge (USA) & 2.600 & 5.13 & 3.00 & 2.470 & 4.80 & 1.67 \\
\hline Imperial Valley (USA) & 1.150 & 4.36 & 2.68 & 1.10 & 3.93 & 2.40 \\
\hline Loma Prieta (USA) & 4.280 & 5.00 & 2.72 & 3.800 & 2.96 & 1.12 \\
\hline Whittier (USA) & 5.000 & 6.25 & 2.47 & 4.750 & 4.83 & 1.67 \\
\hline San Fernando & 8.150 & 5.25 & 2.60 & 6.500 & 4.32 & 1.67 \\
\hline
\end{tabular}


Table 4: MIDs and MRIDs at Sa causing failure of the steel frame

\begin{tabular}{|c|c|c|c|c|c|c|c|c|c|c|c|c|c|c|c|c|}
\hline & \multicolumn{2}{|c|}{$\begin{array}{c}\text { Frame } 1 \\
\text { (Steel frame) }\end{array}$} & \multicolumn{2}{|c|}{$\begin{array}{l}\text { Frame } 2 \\
\text { (48 SMA } \\
\text { sections) }\end{array}$} & \multicolumn{2}{|c|}{$\begin{array}{c}\text { Frame } 3 \\
\text { (5 SMA sections) }\end{array}$} & \multicolumn{2}{|c|}{$\begin{array}{c}\text { Frame } 4 \\
\text { (8 SMA } \\
\text { sections) }\end{array}$} & \multicolumn{2}{|c|}{$\begin{array}{c}\text { Frame } 5 \\
\text { (8 SMA } \\
\text { sections) }\end{array}$} & \multicolumn{2}{|c|}{$\begin{array}{c}\text { Frame } 6 \\
\text { (8 SMA } \\
\text { sections) }\end{array}$} & \multicolumn{2}{|c|}{$\begin{array}{l}\text { Frame } 7 \\
\text { (8 SMA } \\
\text { sections) }\end{array}$} & \multicolumn{2}{|c|}{$\begin{array}{l}\text { Frame } 8 \\
\text { (16 SMA } \\
\text { sections) }\end{array}$} \\
\hline & $\begin{array}{l}\text { MID } \\
(\%)\end{array}$ & $\begin{array}{c}\text { MRID } \\
(\%)\end{array}$ & $\begin{array}{l}\text { MID } \\
(\%)\end{array}$ & $\begin{array}{c}\text { MRID } \\
(\%)\end{array}$ & $\begin{array}{l}\text { MID } \\
(\%)\end{array}$ & $\begin{array}{c}\text { MRID } \\
(\%)\end{array}$ & $\begin{array}{l}\text { MID } \\
(\%)\end{array}$ & $\begin{array}{c}\text { MRID } \\
(\%)\end{array}$ & $\begin{array}{l}\text { MID } \\
(\%)\end{array}$ & $\begin{array}{c}\text { MRID } \\
(\%)\end{array}$ & $\begin{array}{l}\text { MID } \\
(\%)\end{array}$ & $\begin{array}{c}\text { MRID } \\
(\%)\end{array}$ & $\begin{array}{l}\text { MID } \\
(\%)\end{array}$ & $\begin{array}{c}\text { MRID } \\
(\%)\end{array}$ & $\begin{array}{l}\text { MID } \\
(\%)\end{array}$ & $\begin{array}{c}\text { MRID } \\
(\%)\end{array}$ \\
\hline $\begin{array}{c}\text { Northridge } \\
(2.47 \mathrm{~g})\end{array}$ & 4.80 & 1.67 & 6.56 & 0.53 & 4.81 & 2.0 & 4.81 & 2.10 & 4.77 & 2.00 & 4.79 & 1.87 & 5.80 & 1.33 & 4.95 & 0.67 \\
\hline $\begin{array}{c}\text { Imperial Valley } \\
(1.10 \mathrm{~g})\end{array}$ & 3.93 & 2.40 & 5.06 & 0.33 & 5.00 & 1.43 & 4.50 & 2.43 & 4.56 & 2.90 & 4.72 & 3.17 & 4.37 & 0.67 & 4.72 & 0.83 \\
\hline $\begin{array}{l}\text { Loma Prieta } \\
(3.80 \mathrm{~g})\end{array}$ & 2.96 & 1.12 & 4.20 & 0.60 & 3.56 & 1.43 & 4.16 & 3.07 & 3.90 & 2.67 & 4.15 & 2.87 & 3.52 & 1.83 & 3.38 & 1.01 \\
\hline Whittier (4.75g) & 4.83 & 1.67 & 6.80 & 1.00 & 5.47 & 0.67 & 4.55 & 1.83 & 4.81 & 2.00 & 4.76 & 1.90 & 4.45 & 0.67 & 4.68 & 0.33 \\
\hline $\begin{array}{c}\text { San Fernando } \\
(6.50 \mathrm{~g})\end{array}$ & 4.32 & 1.67 & 5.24 & 0.80 & 4.76 & 1.17 & 3.86 & 1.37 & 4.07 & 1.60 & 4.28 & 1.77 & 4.54 & 0.80 & 4.56 & 0.7 \\
\hline Average value & 4.17 & 1.71 & 5.57 & 0.65 & 4.46 & 1.34 & 4.38 & 2.16 & 4.42 & 2.23 & 4.54 & 2.32 & 4.54 & 1.06 & 4.46 & 0.71 \\
\hline $\begin{array}{l}\text { Percent of } \\
\text { change }\end{array}$ & NA & NA & 33.69 & -61.78 & 6.96 & -21.45 & 4.99 & 26.61 & 6.09 & 30.95 & 8.93 & 35.76 & 8.83 & -37.87 & 6.96 & -58.50 \\
\hline
\end{tabular}

${ }^{*}$ The percent of change is referenced to the steel RC frame

Table 5: MID, MRID and storey experiencing severe damage for the SMA RC frame at failure

\begin{tabular}{|c|c|c|c|c|}
\hline \multirow{2}{*}{ Earthquake record } & \multicolumn{2}{|c|}{ Storey experienced MID } & \multicolumn{2}{c|}{ Storey experienced MRID } \\
\cline { 2 - 5 } & Storey No. & MID (\%) & Storey No. & MRID (\%) \\
\hline Northridge (3.10g) & $3^{\text {rd }}$ & 7.38 & $3^{\text {rd }}$ & 2.00 \\
\hline Imperial Valley (1.20g) & $2^{\text {nd }}$ & 6.53 & $3^{\text {rd }}$ & 1.5 \\
\hline Loma Prieta (4.75g) & $1^{\text {st }}$ & 4.19 & $5^{\text {th }}$ & 1.67 \\
\hline Whittier $(5.70 \mathrm{~g})$ & $1^{\text {st }}$ & 6.25 & $5^{\text {th }}$ & 1.00 \\
\hline Sanfernando $(8.00 \mathrm{~g})$ & $3^{\text {rd }}$ & 5.96 & $3^{\text {rd }}$ & 1.67 \\
\hline
\end{tabular}




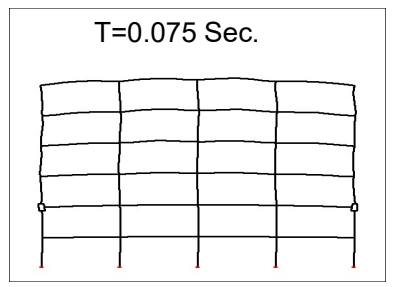

Mode 1

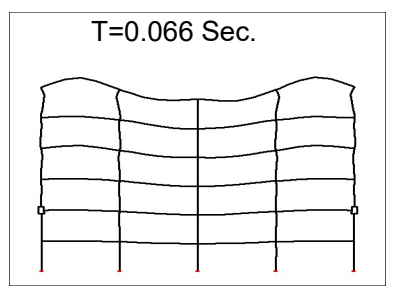

Mode 3

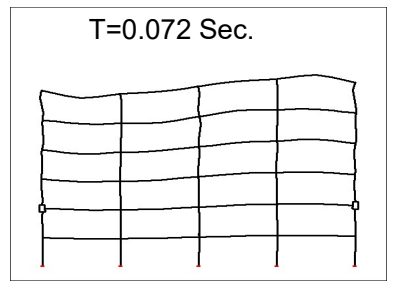

Mode 2

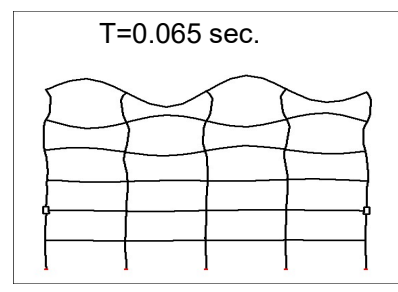

Mode 4

Figure 1: First four vertical mode shapes of the six-storey steel RC building 


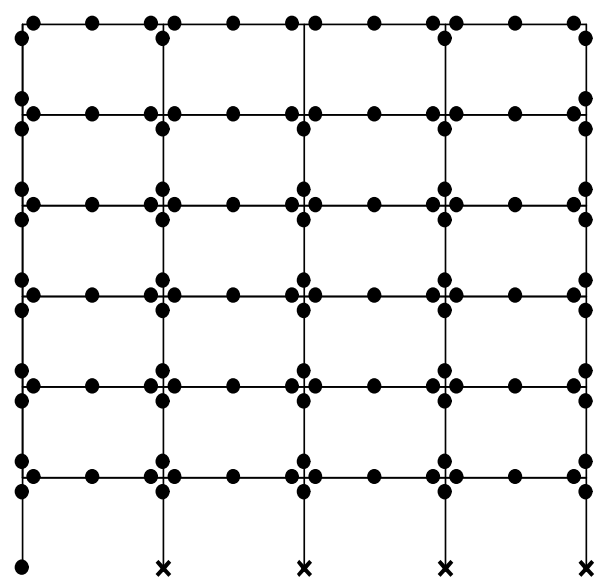

Imperial Valley $1.10 \mathrm{~g}$

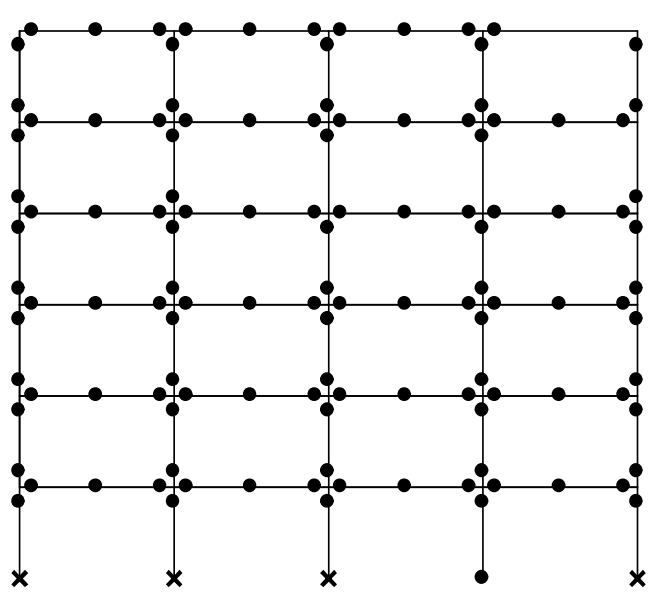

Sanfernando $6.50 \mathrm{~g}$

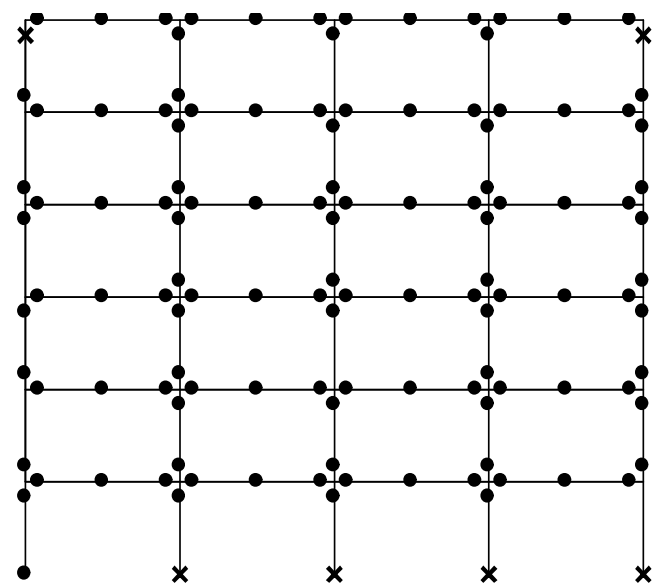

Northridge $2.47 \mathrm{~g}$

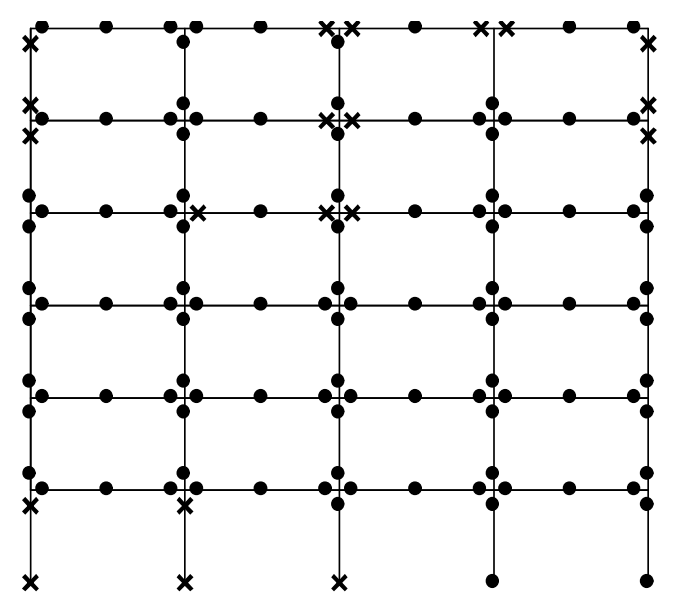

Whittier $4.75 \mathrm{~g}$

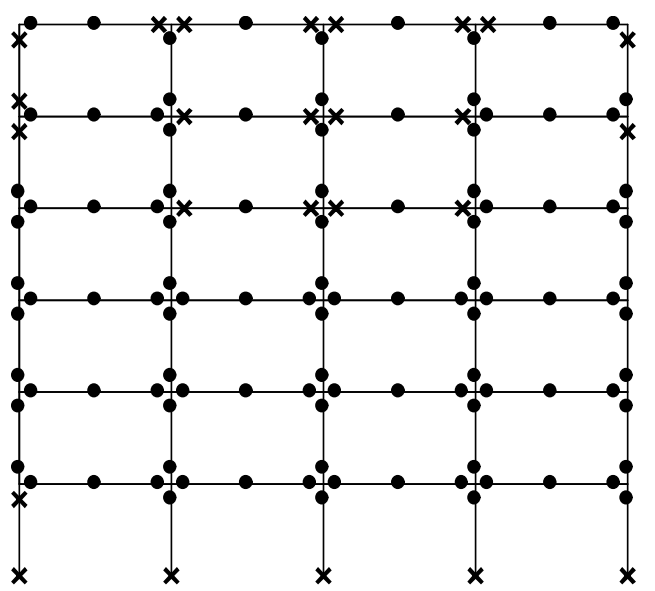

Loma Prieta $3.80 \mathrm{~g}$

Figure 2: Damage Schemes of the Steel RC frame at collapse 


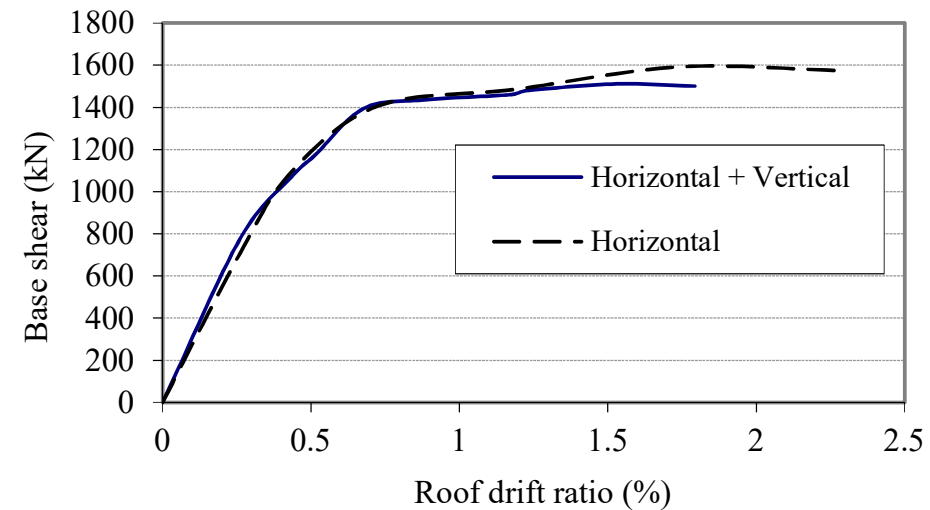

Figure 3: Relationship between the base shear and the roof drift 


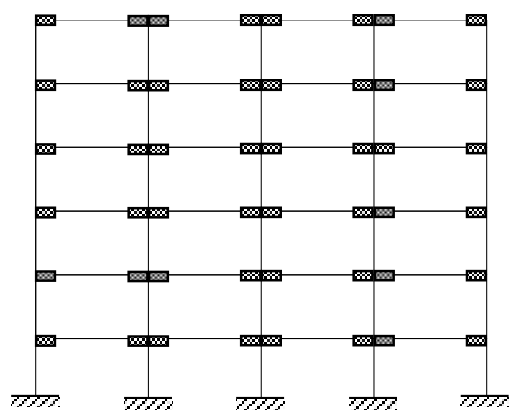

Frame 2

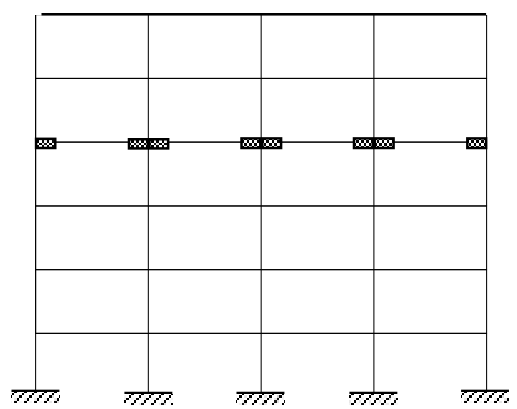

Frame 4

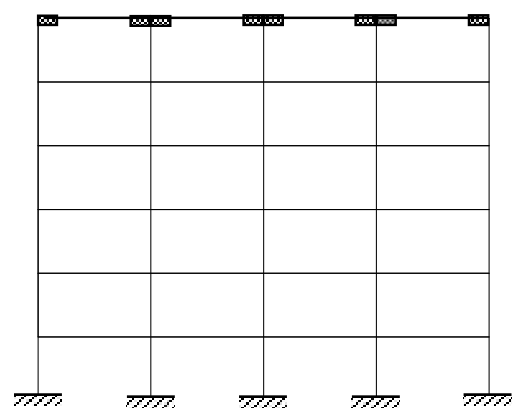

Frame 6

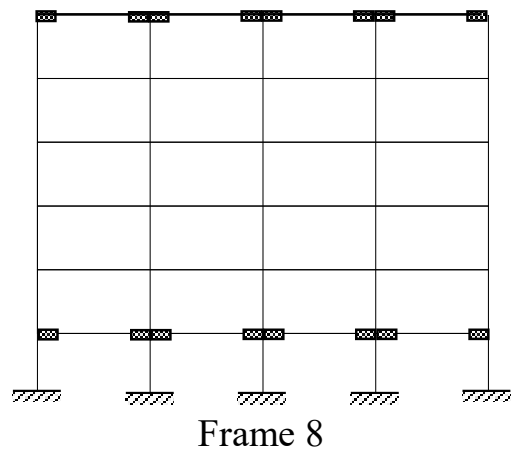

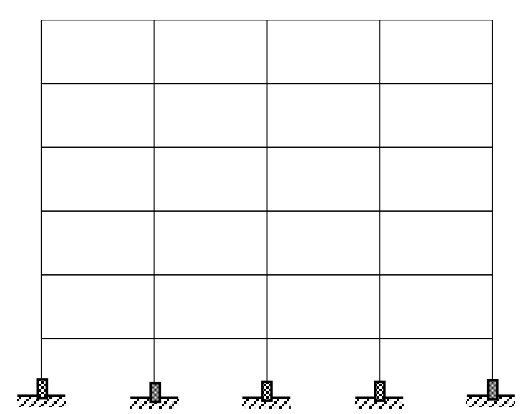

Frame 3

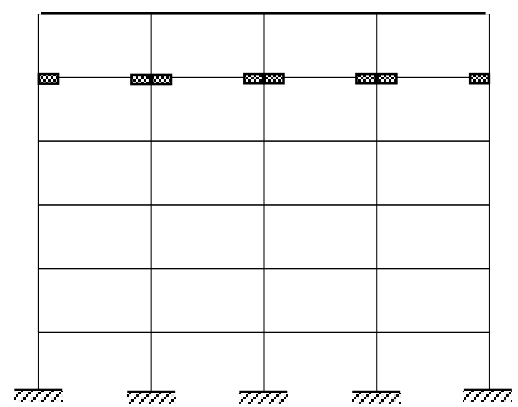

Frame 5

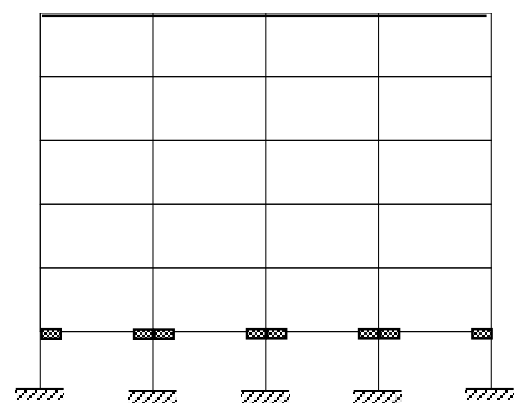

Frame 7

Figure 4: Locations of SMA bars in the selected SMA RC frames 


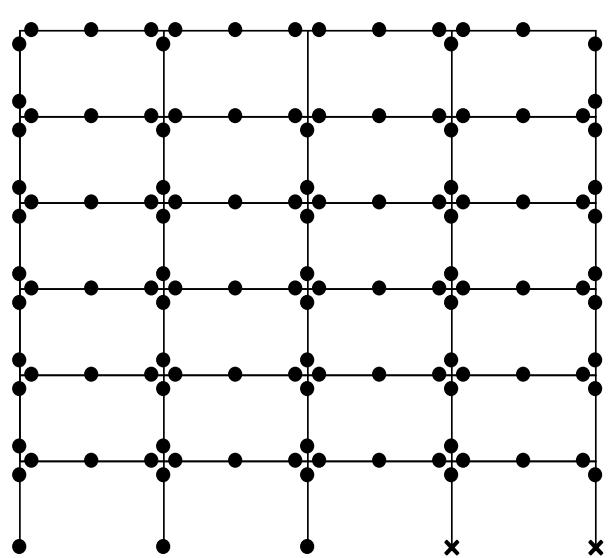

Imperial Valley $1.10 \mathrm{~g}$

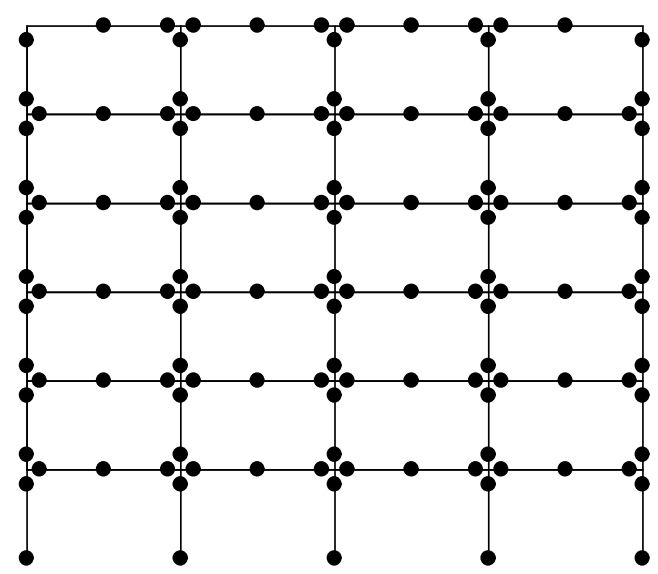

Sanfernando $6.50 \mathrm{~g}$

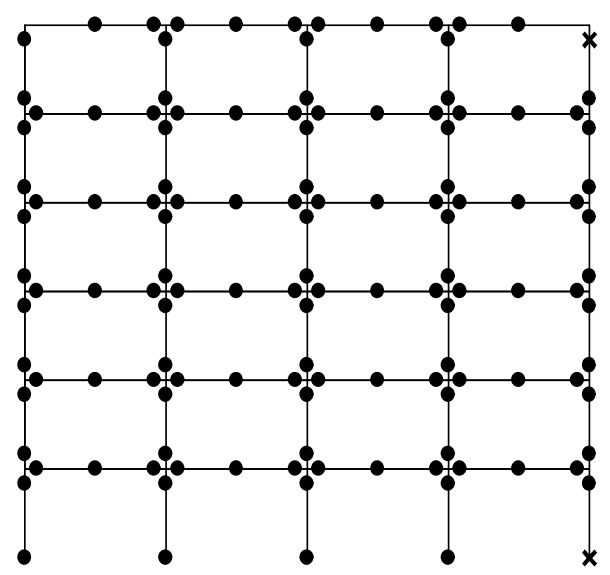

Northridge $2.47 \mathrm{~g}$

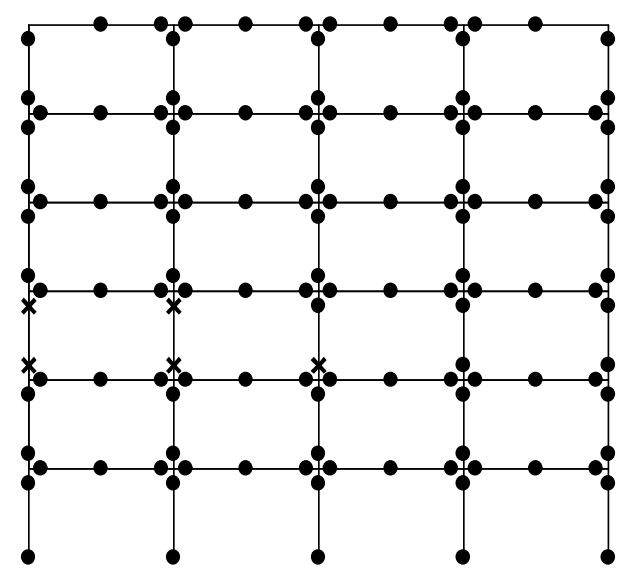

Whittier $4.75 \mathrm{~g}$

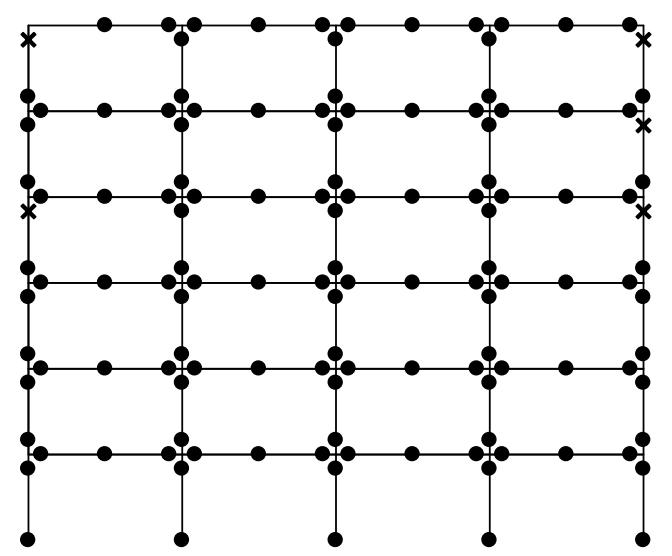

Loma Prieta $3.80 \mathrm{~g}$

Figure 5: Damage in Frame 2 (SMA at the ends of all beams) 


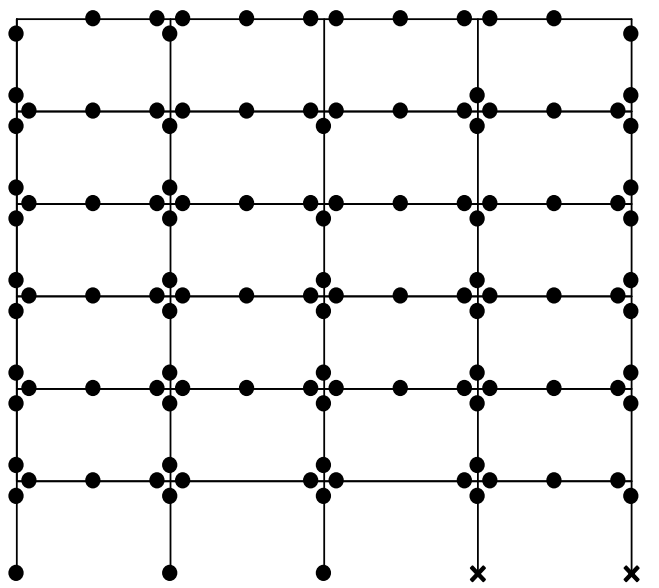

Imperial Valley $1.10 \mathrm{~g}$

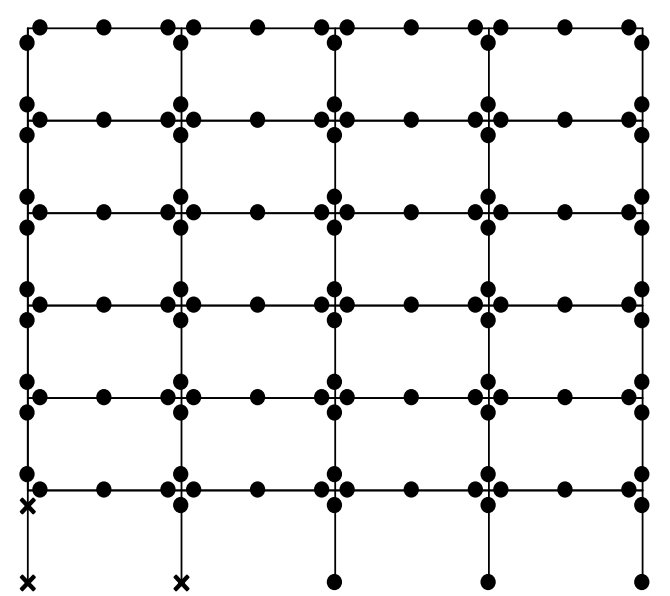

Sanfernando $6.50 \mathrm{~g}$

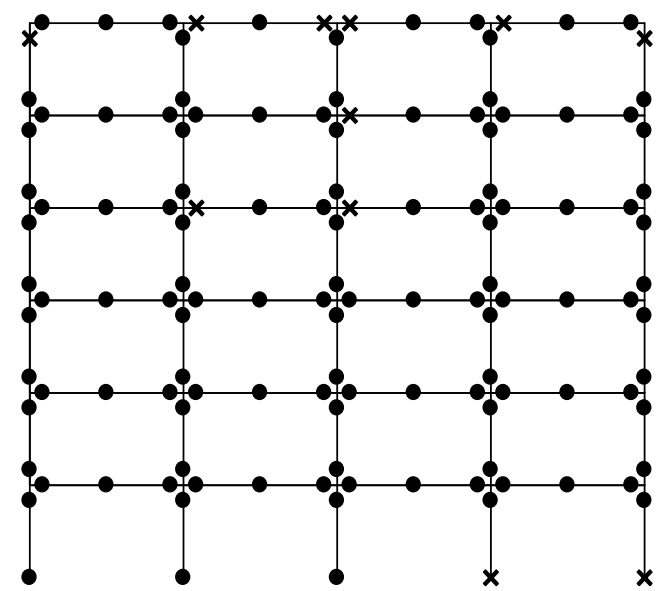

Northridge $2.47 \mathrm{~g}$

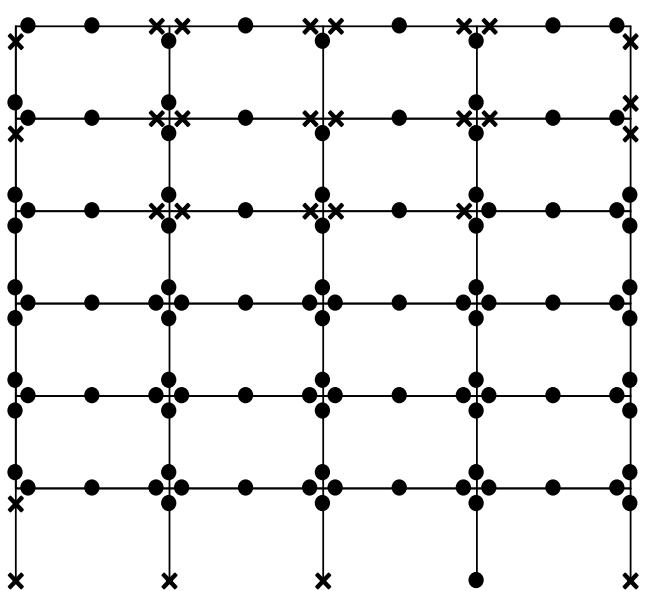

Whittier $4.75 \mathrm{~g}$

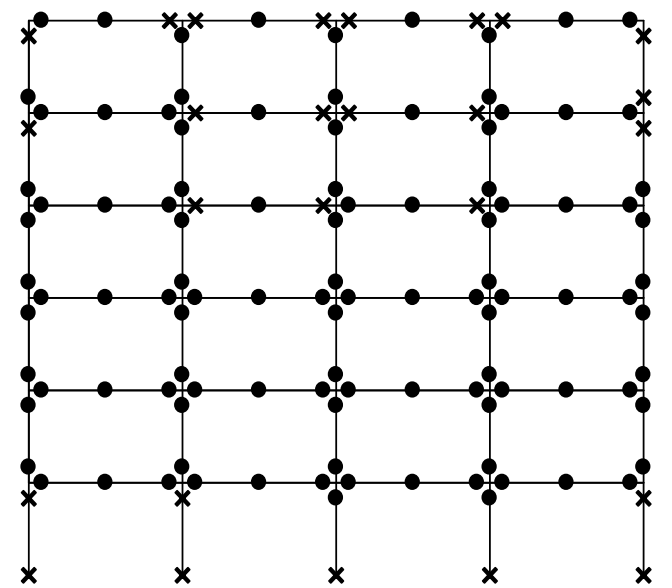

Loma Prieta $3.80 \mathrm{~g}$

Figure 6: Damage in Frame 3 (SMA at the lower ends of all the first storey columns) 


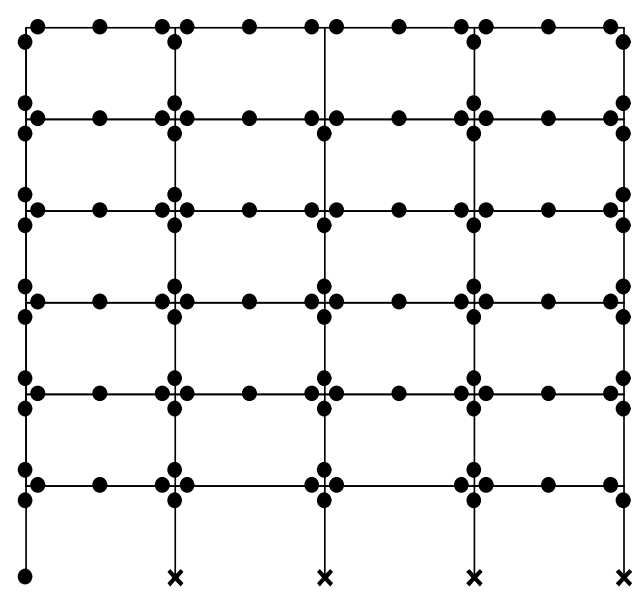

Imperial Valley $1.10 \mathrm{~g}$

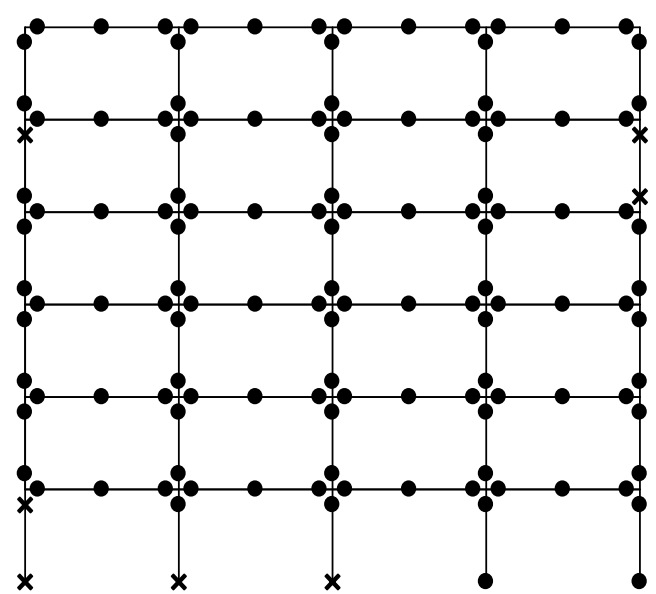

Sanfernando $6.50 \mathrm{~g}$

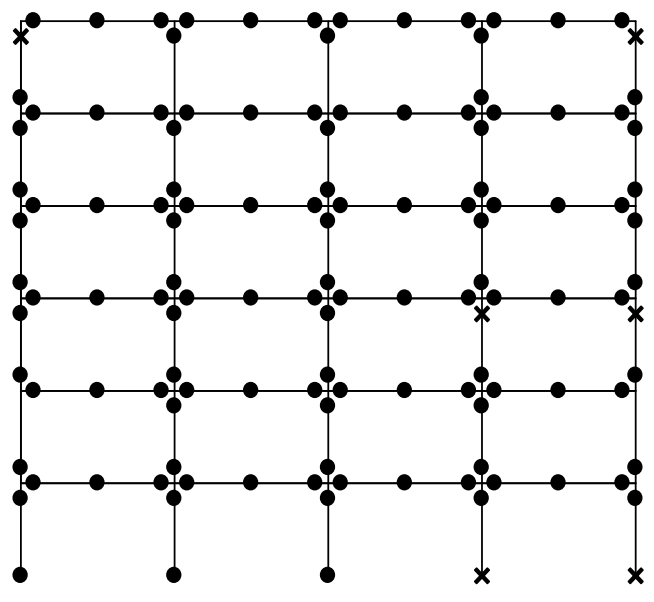

Northridge $2.47 \mathrm{~g}$

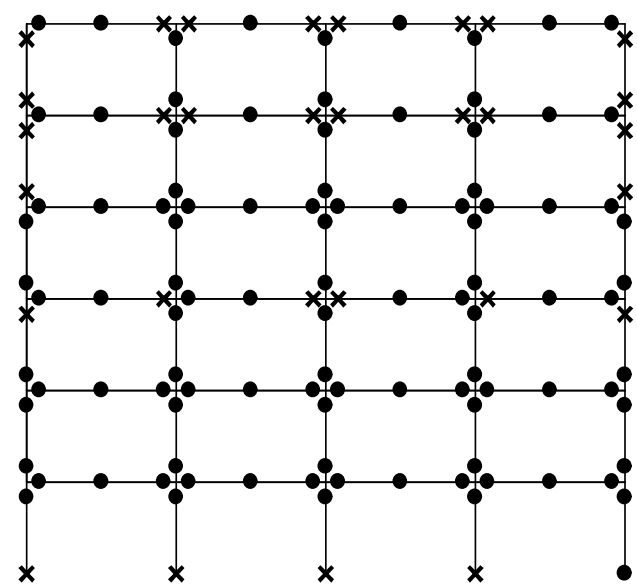

Whittier $4.75 \mathrm{~g}$

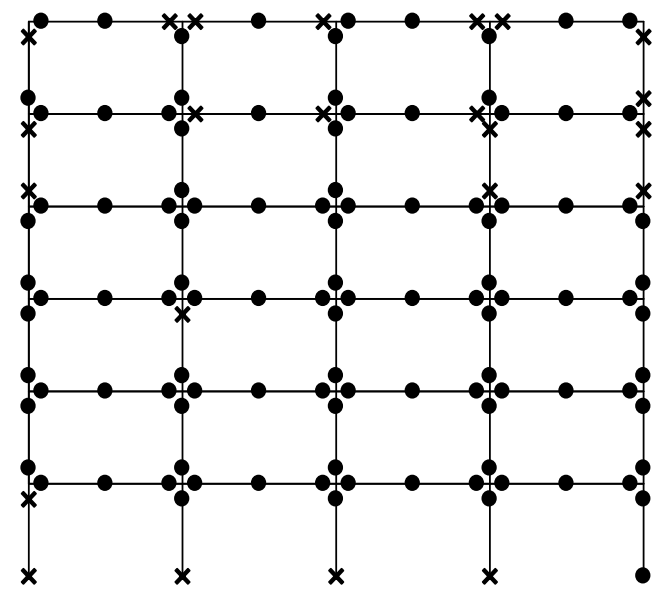

Loma Prieta $3.80 \mathrm{~g}$

Figure 7: Damage in Frame 4 (SMA at the ends of the fourth floor beams) 


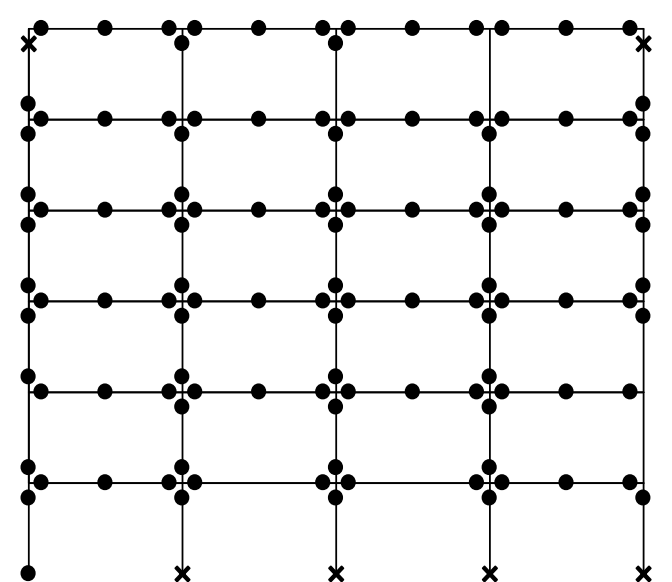

Imperial Valley $1.10 \mathrm{~g}$

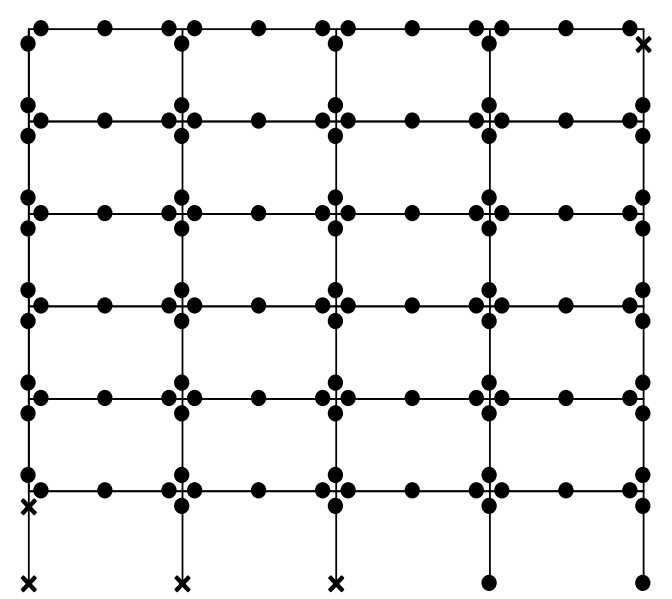

Sanfernando $6.50 \mathrm{~g}$

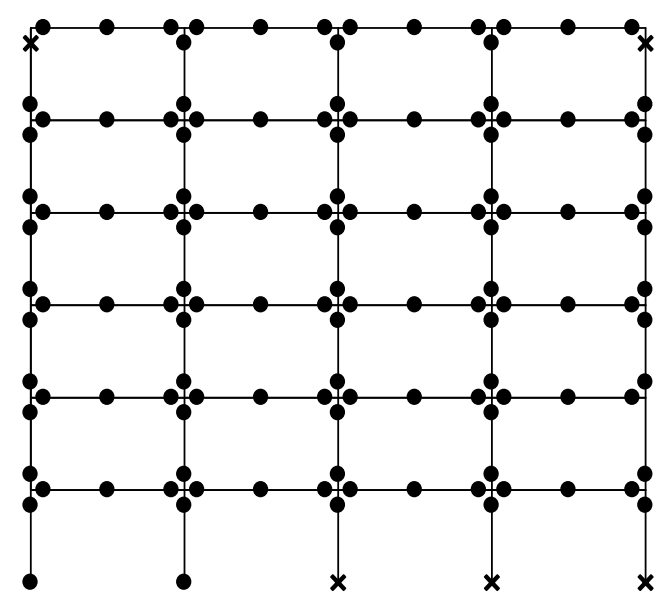

Northridge $2.47 \mathrm{~g}$

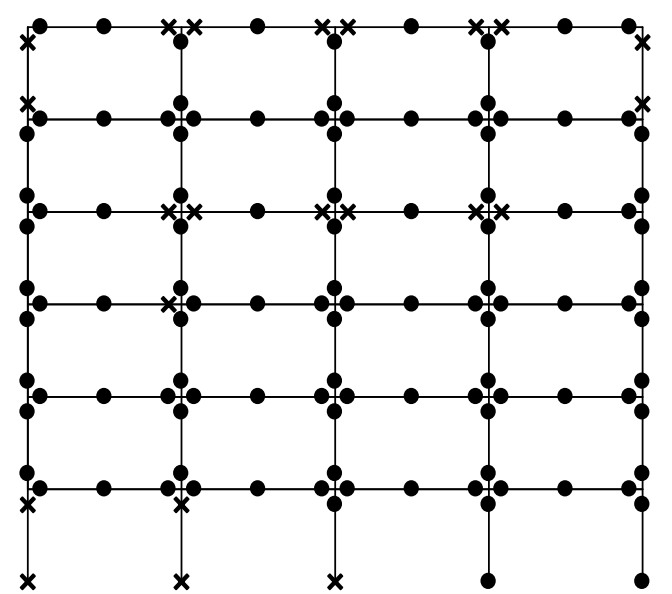

Whittier $4.75 \mathrm{~g}$

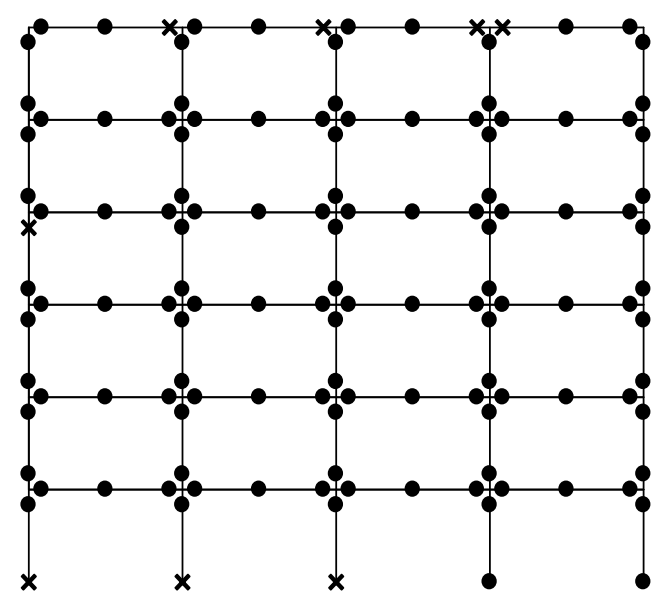

Loma Prieta $3.80 \mathrm{~g}$

Figure 8: Damage in Frame 5 (SMA at the ends of the Fifth floor beams) 


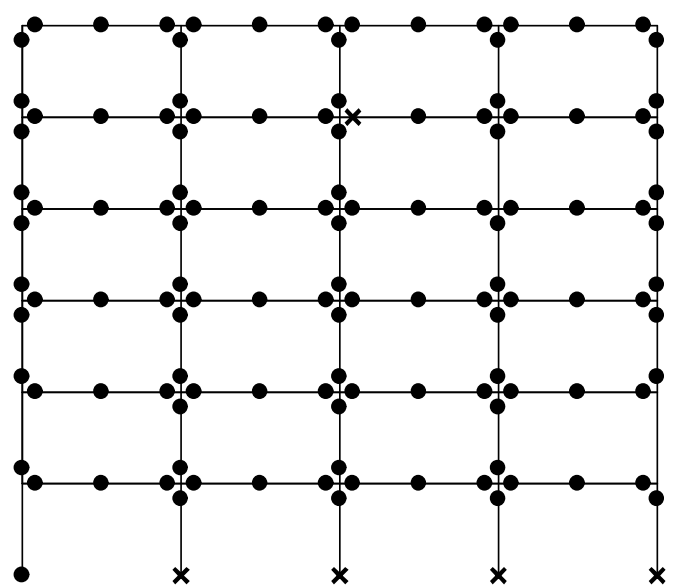

Imperial Valley $1.10 \mathrm{~g}$

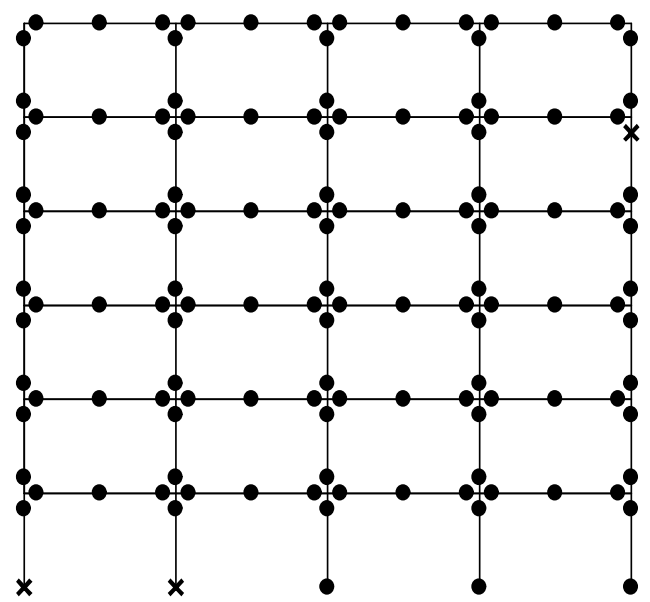

Sanfernando $6.50 \mathrm{~g}$

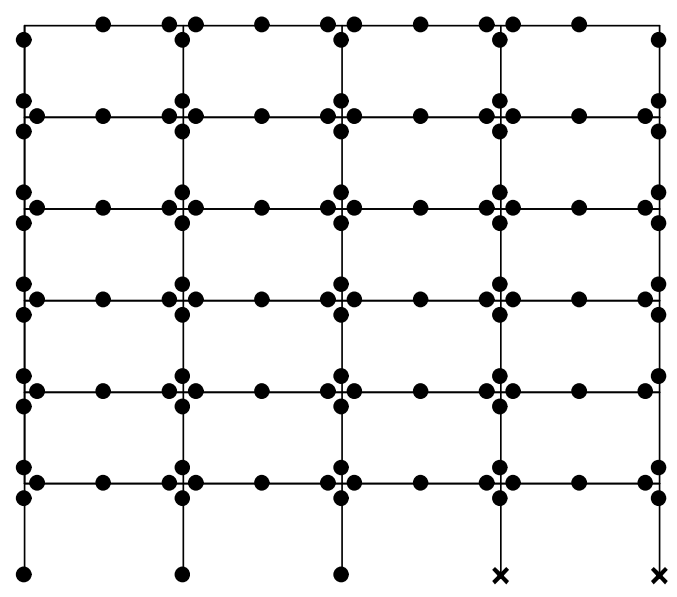

Northridge $2.47 \mathrm{~g}$

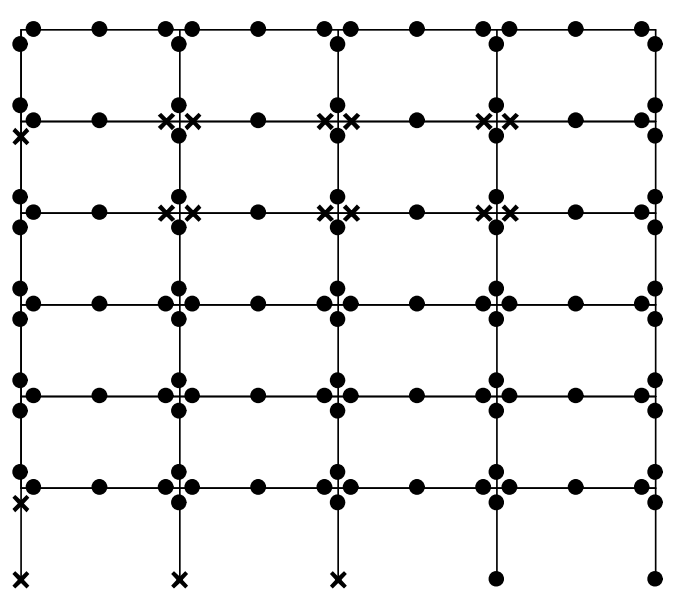

Whittier $4.75 \mathrm{~g}$

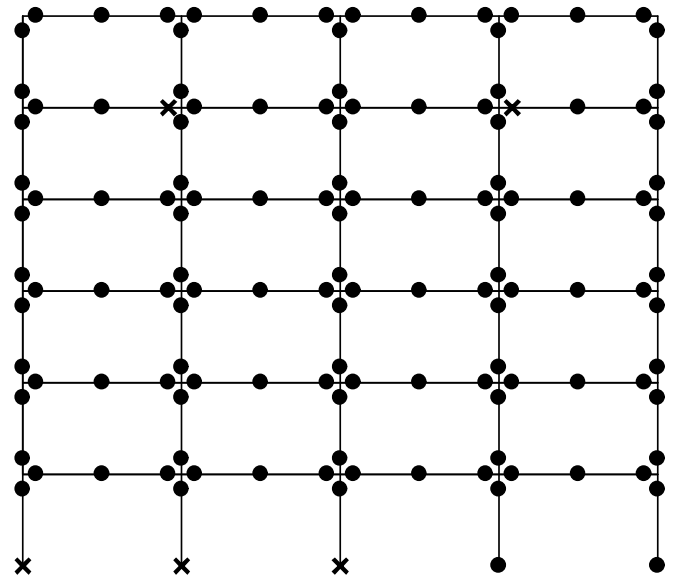

Loma Prieta $3.80 \mathrm{~g}$

Figure 9: Damage in Frame 6 (SMA at the ends of the sixth floor beams) 


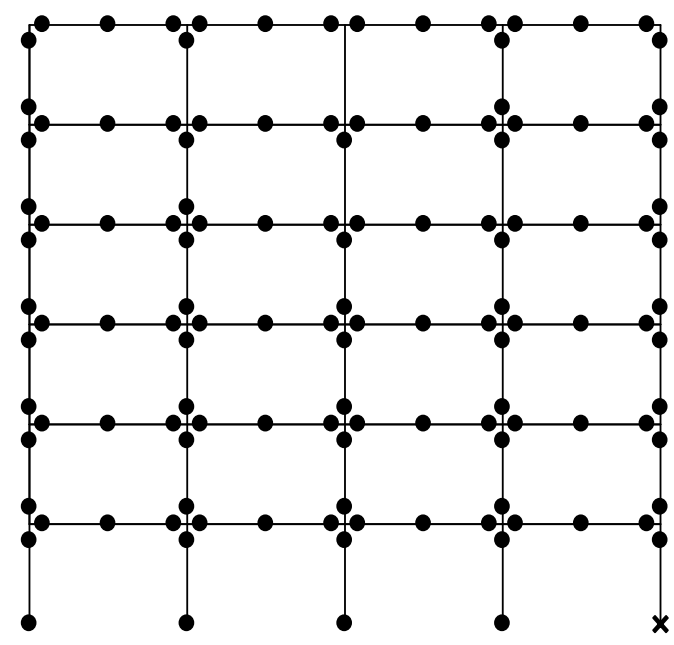

Imperial Valley $1.10 \mathrm{~g}$

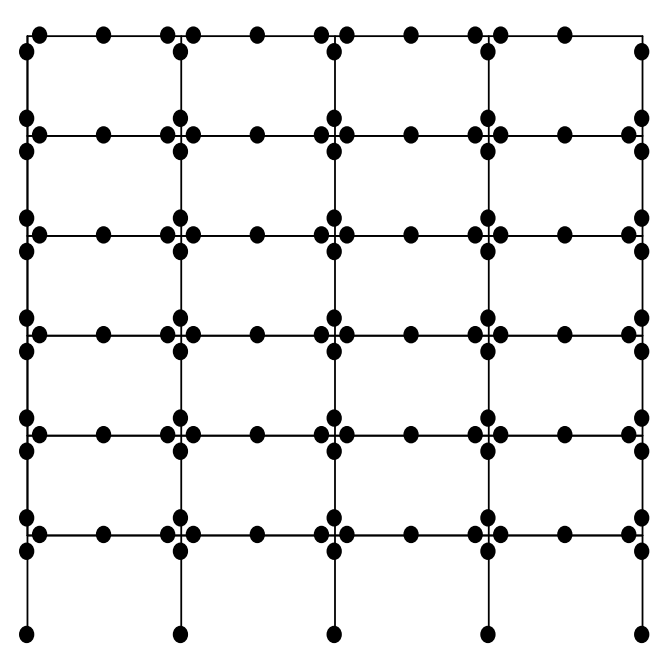

Sanfernando $6.50 \mathrm{~g}$

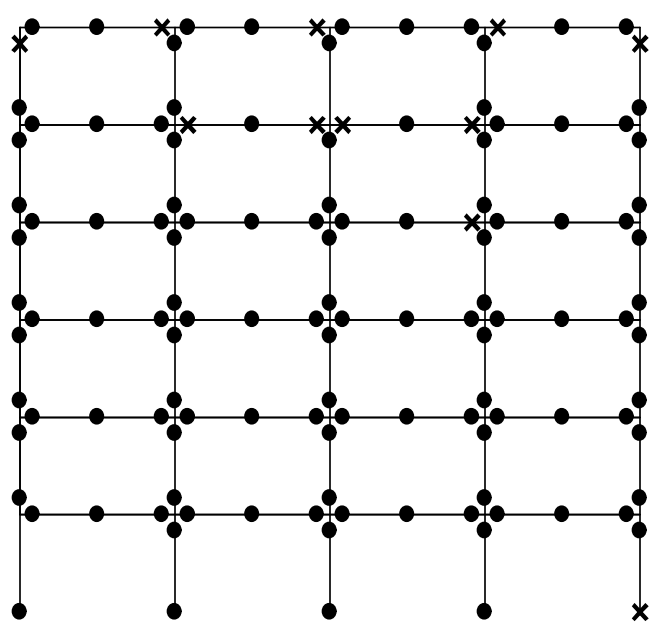

Northridge $2.47 \mathrm{~g}$

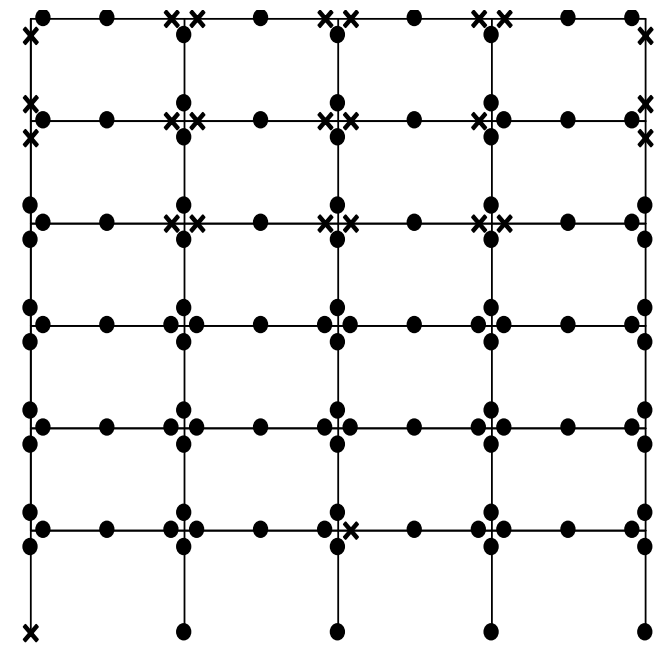

Whittier $4.75 \mathrm{~g}$

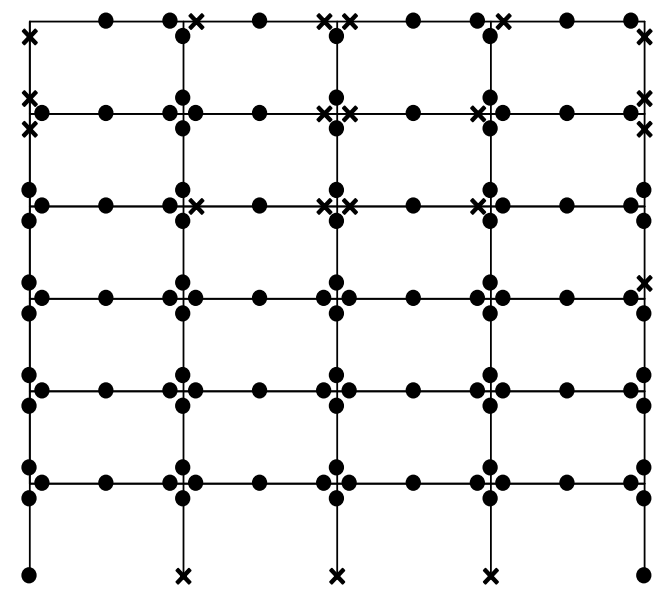

Loma Prieta $3.80 \mathrm{~g}$

Figure 10: Damage in Frame 7 (SMA at the ends of the first floor beams) 


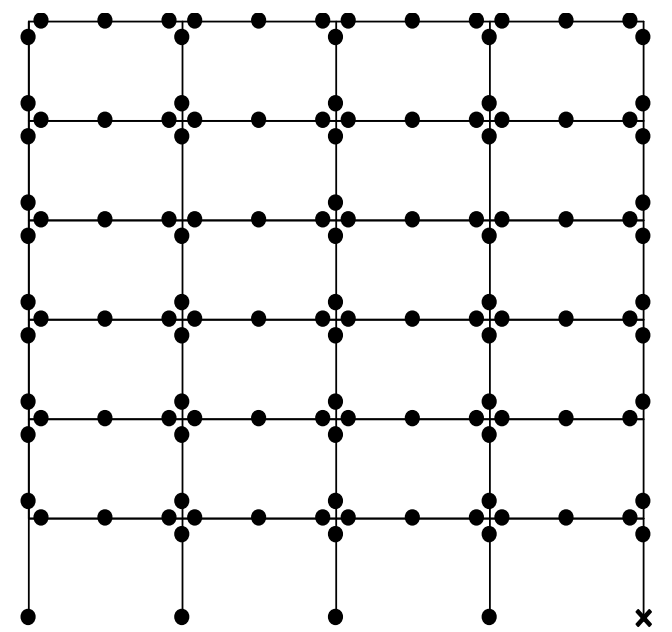

Imperial Valley $1.10 \mathrm{~g}$

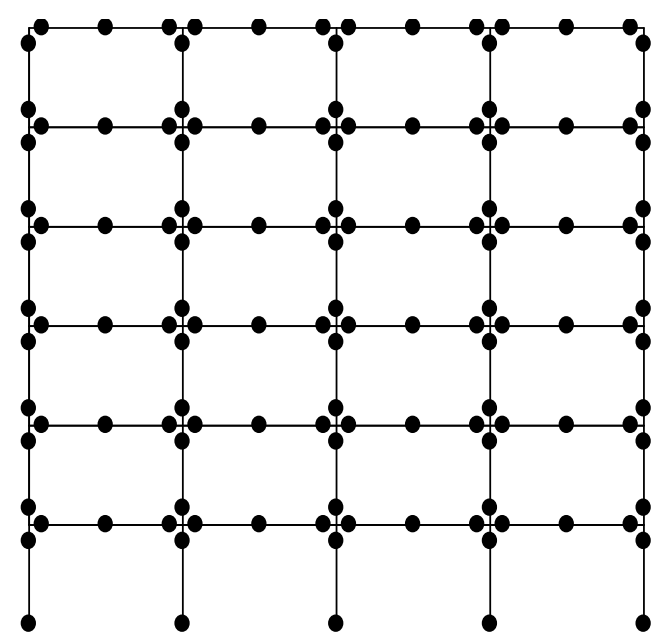

Sanfernando $6.50 \mathrm{~g}$

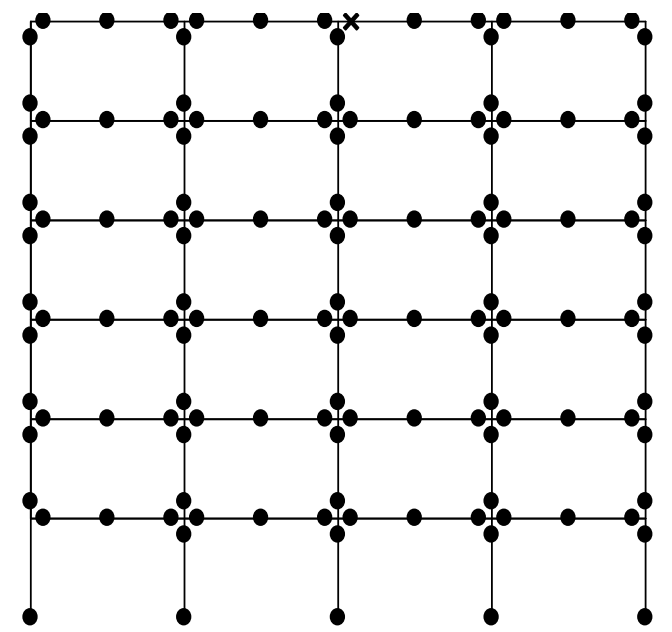

Northridge $2.47 \mathrm{~g}$

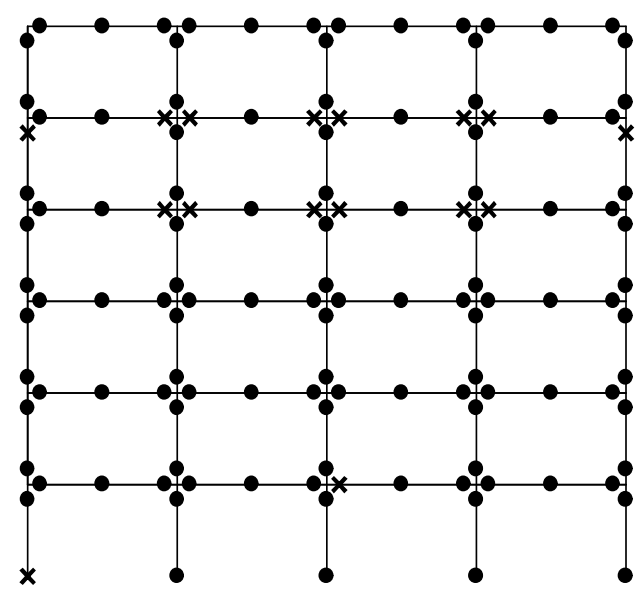

Whittier $4.75 \mathrm{~g}$

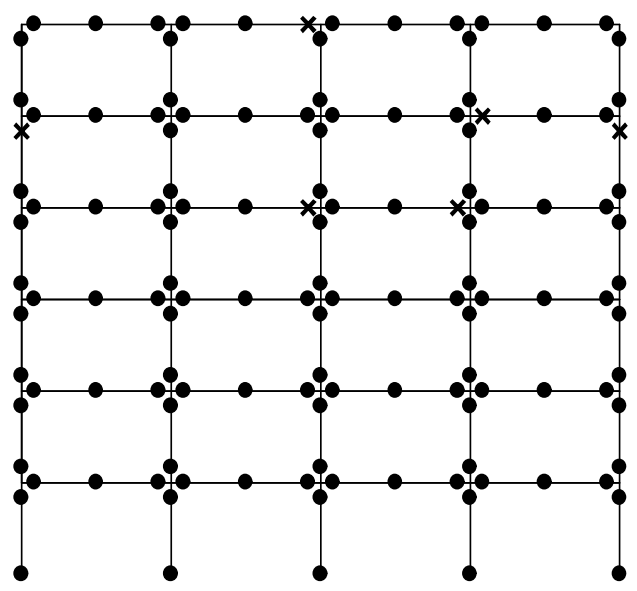

Loma Prieta $3.80 \mathrm{~g}$

Figure 11: Damage in Frame 8 (SMA at the ends of the first and the sixth floor beams) 


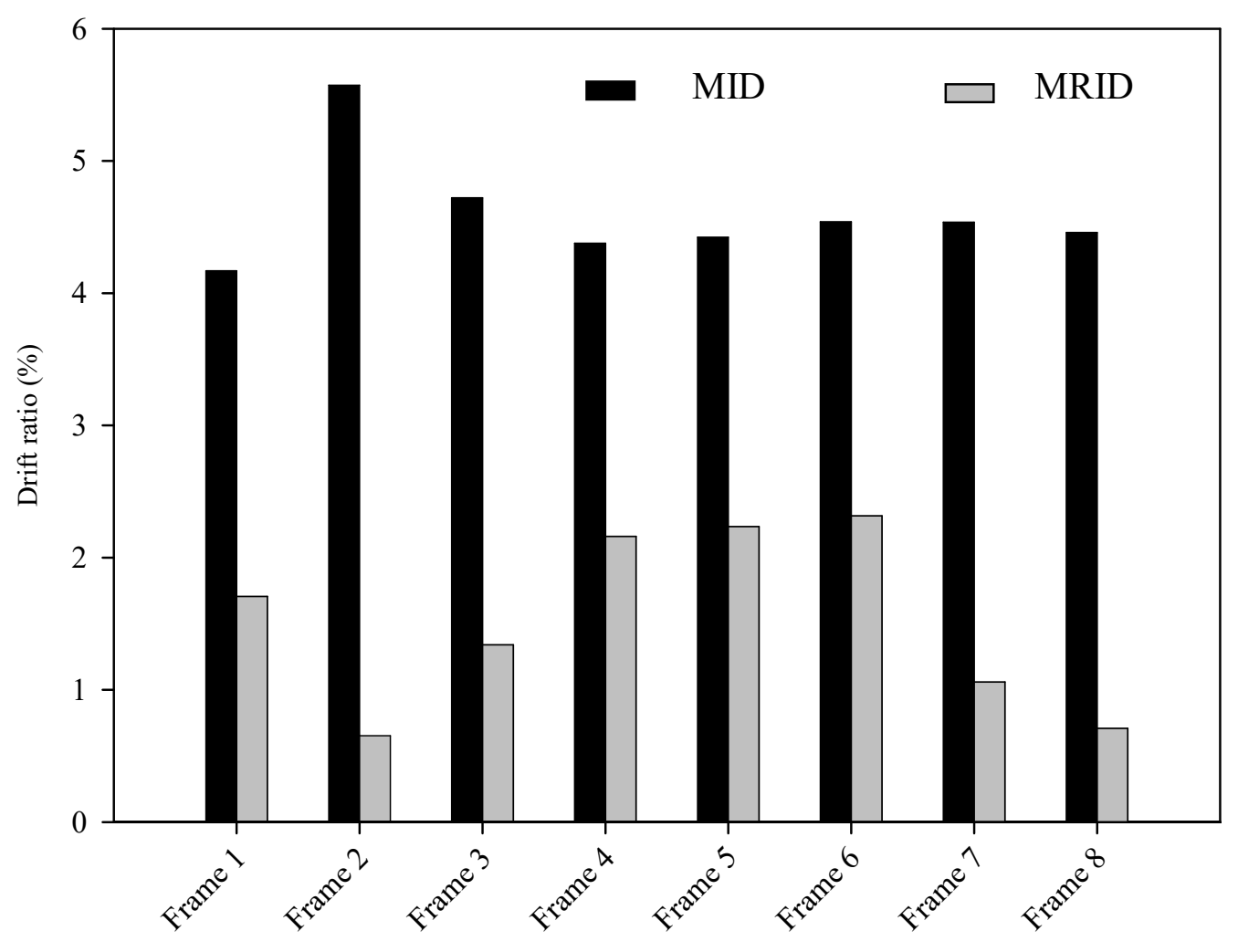

Frame Number

Figure 12: Average values of MIDs and MRIDs at failure of Frame 1 


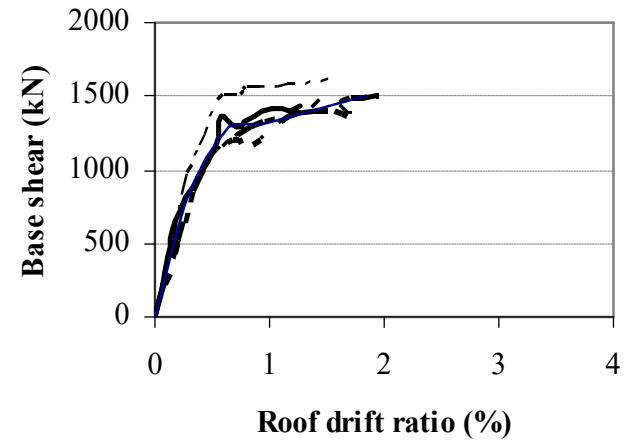

(a) Steel RC Frame (Frame 1)

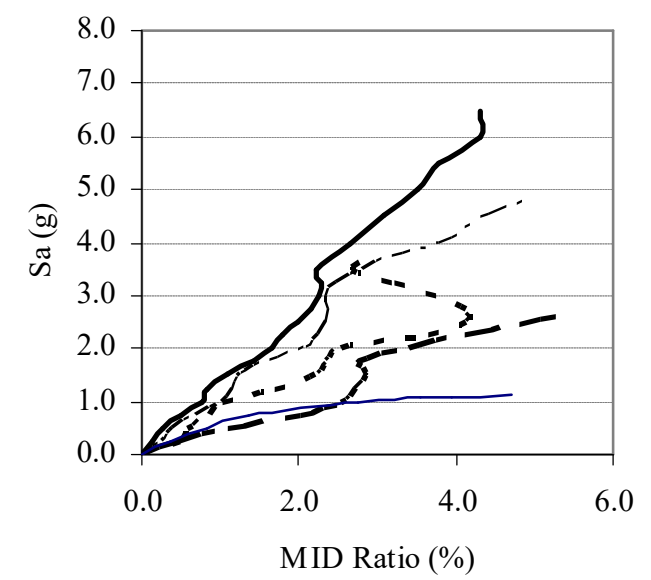

(c) Steel RC Frame (Frame 1)

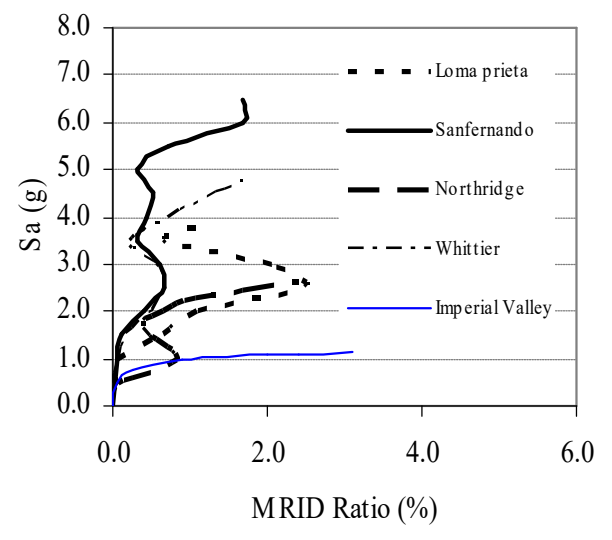

(e) Steel RC Frame (Frame 1)

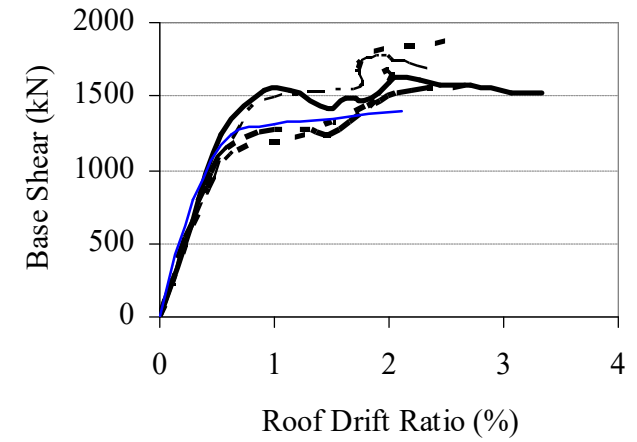

(b) SMA Frame (Frame 8)

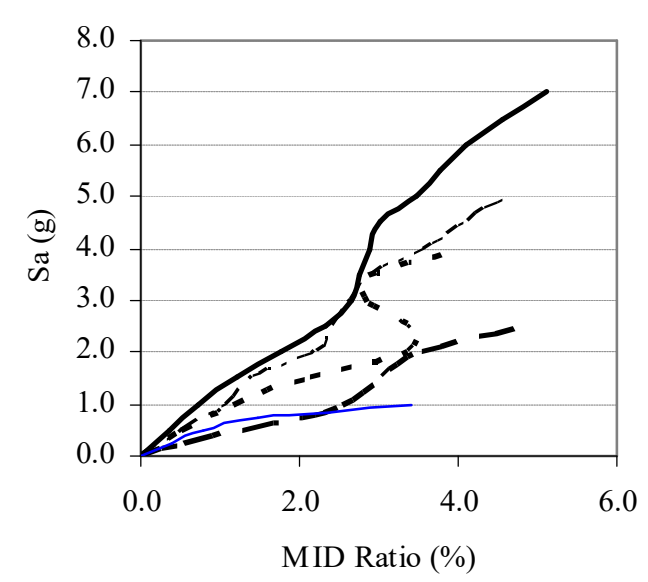

(d) SMA Frame (Frame 8)

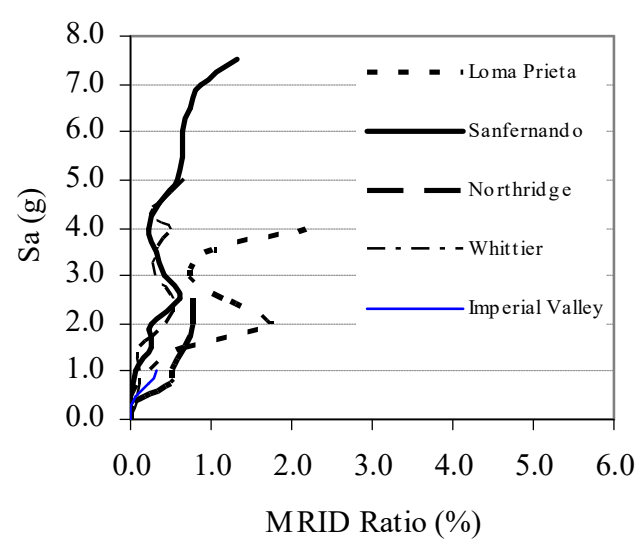

(f) SMA Frame (Frame 8)

Figure 13: IDA results 


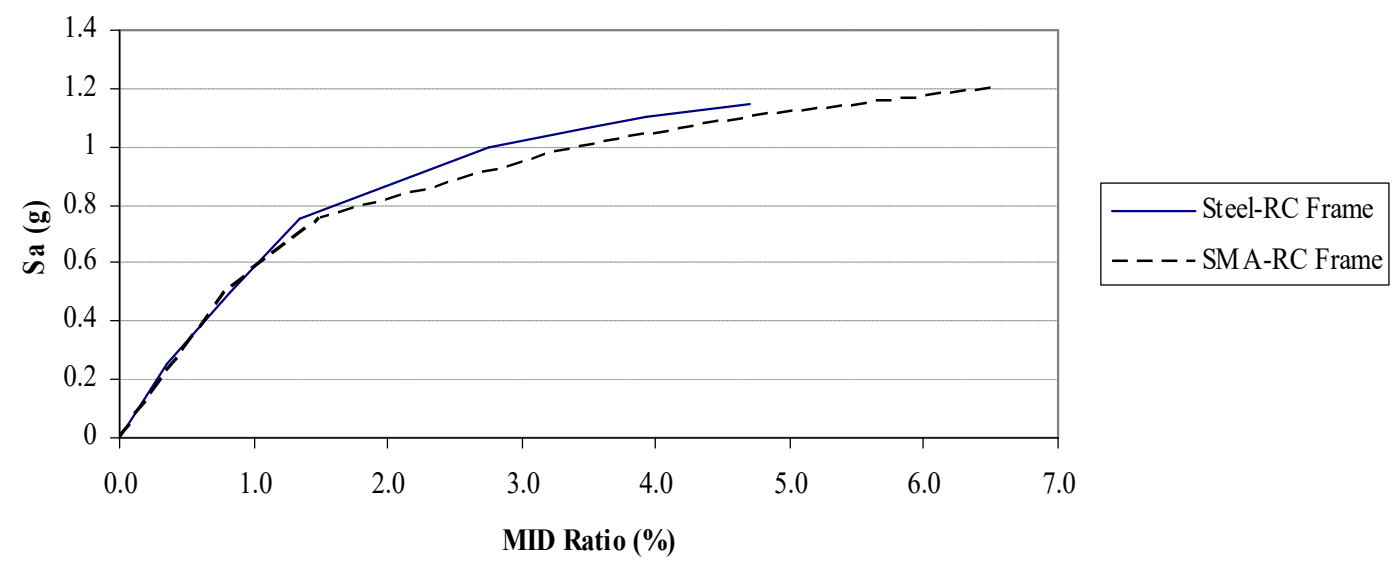

a) Variation of MID values with $\mathrm{Sa}$ (Imperial Valley record)

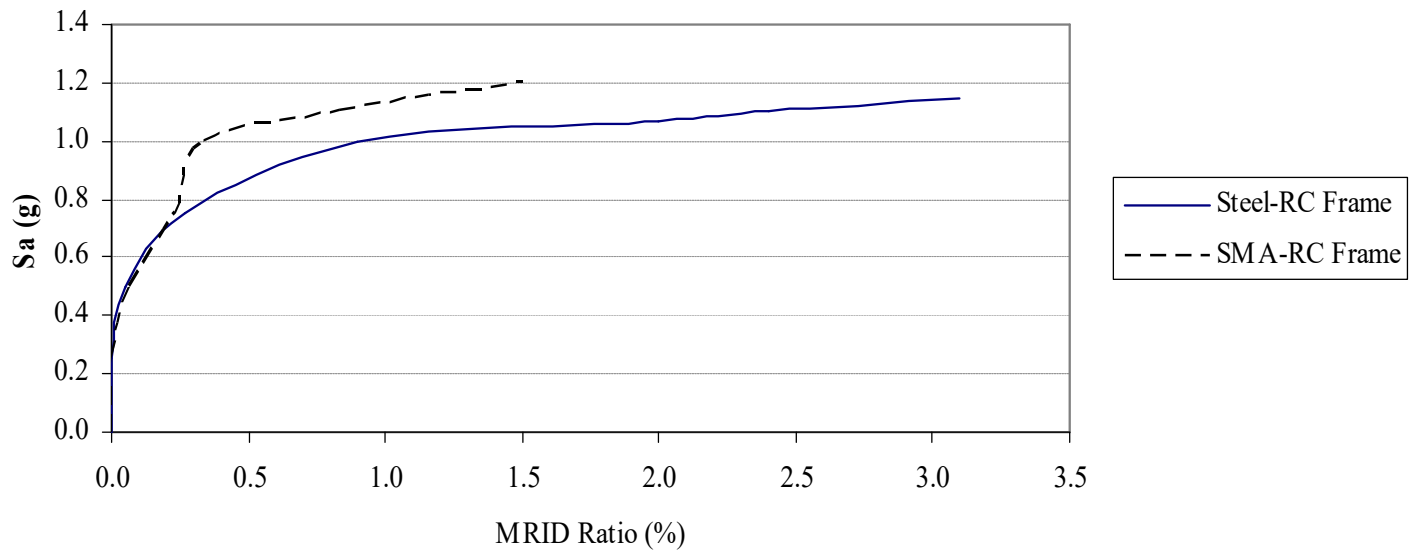

b) Variation of MRID values with Sa (Imperial Valley record)

Figure 14: Variation of drift values using Imperial Valley record 


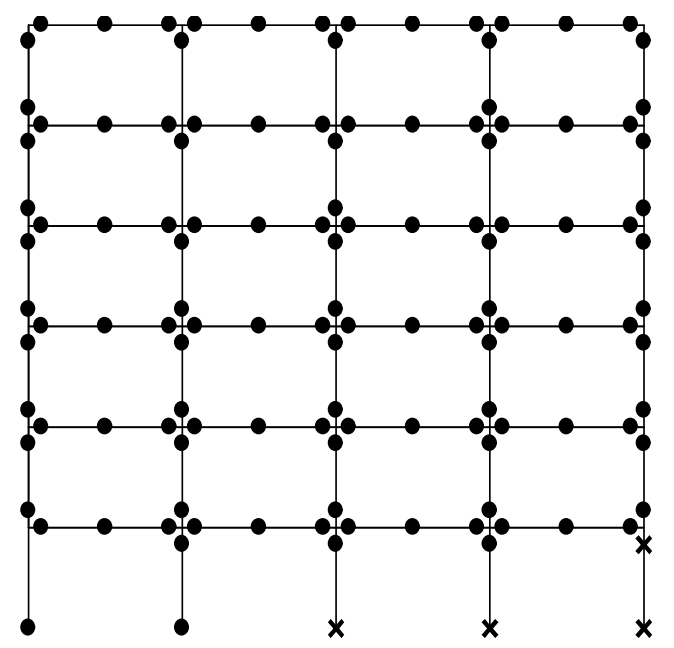

Imperial Valley $1.20 \mathrm{~g}$

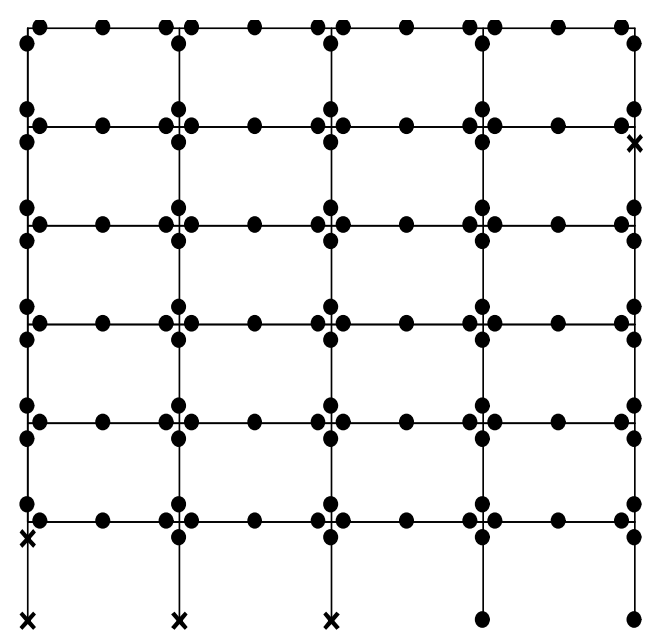

Sanfernando $8.00 \mathrm{~g}$

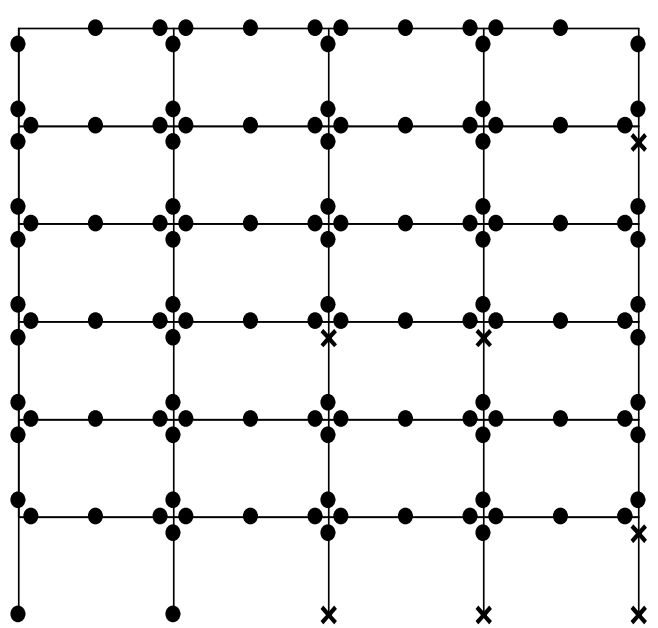

Northridge $3.10 \mathrm{~g}$

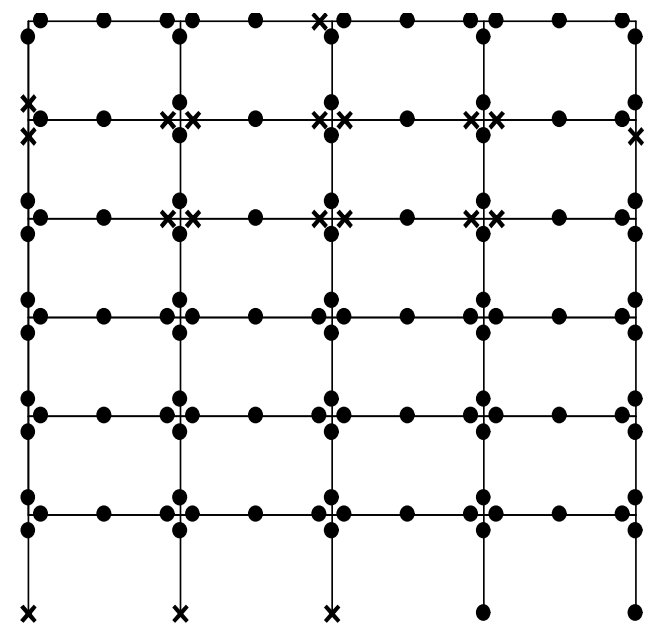

Whittier $5.70 \mathrm{~g}$

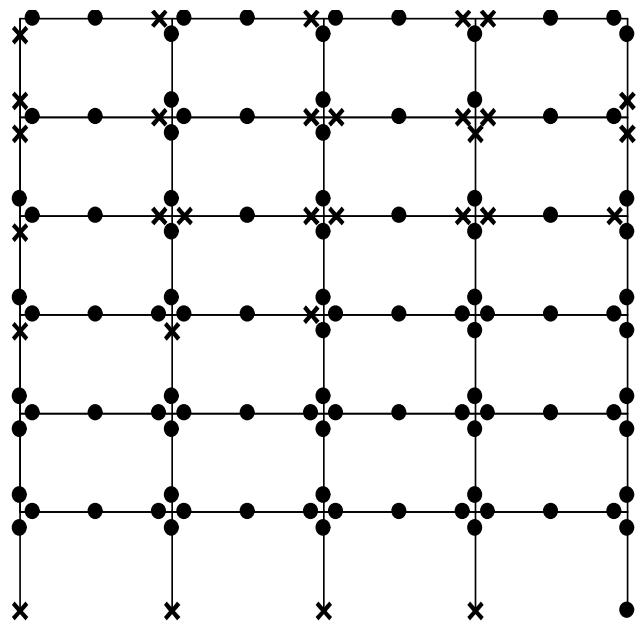

Loma Prieta $4.75 \mathrm{~g}$

Figure 15: Damage in case of Frame 8 at its collapse 


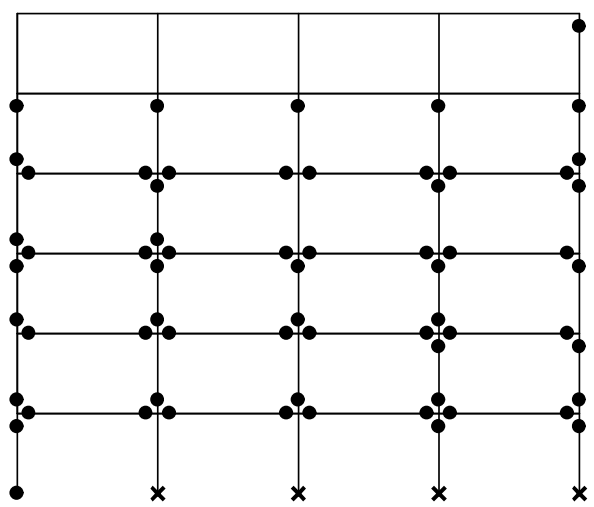

Imperial Valley $(1.15 \mathrm{~g})$

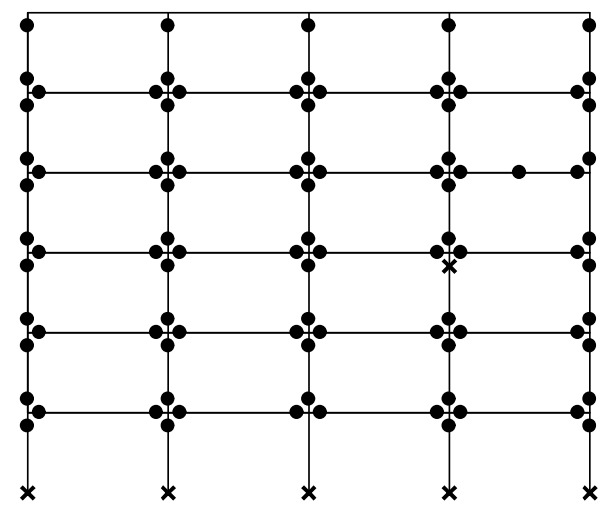

Sanfernando $(8.15 \mathrm{~g})$

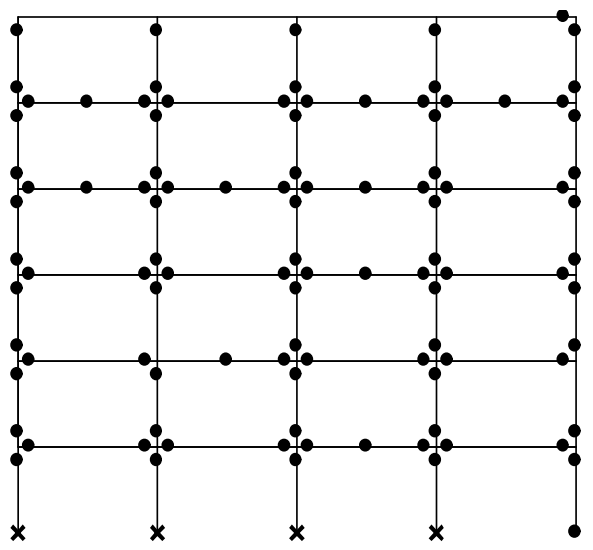

Loma Prieta $(4.28 \mathrm{~g})$

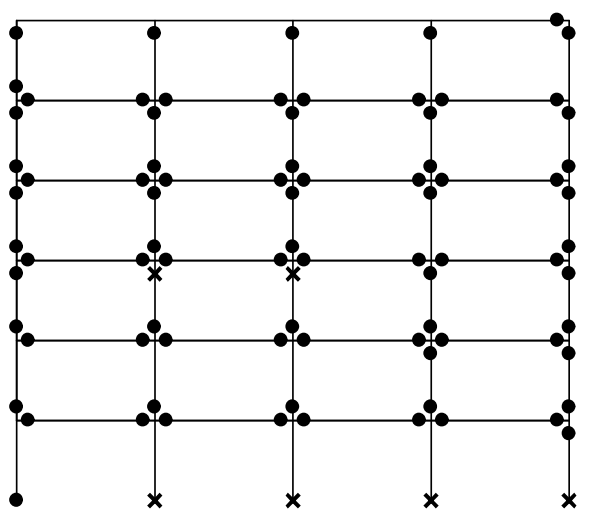

Northridge $(2.60 \mathrm{~g})$

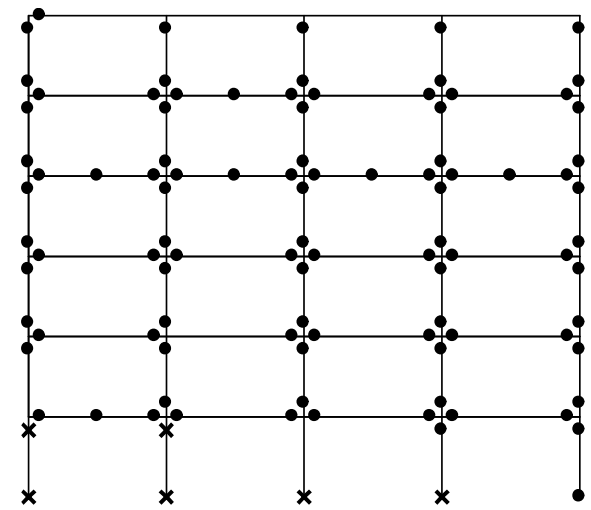

Whittier $(5.00 \mathrm{~g})$

\section{$\begin{array}{ll}\text { Yielding } & \bullet \\ \text { Crushing } & \mathrm{x}\end{array}$}

Figure 16: Damage Scheme of Steel RC frame at collapse using the horizontal seismic component 


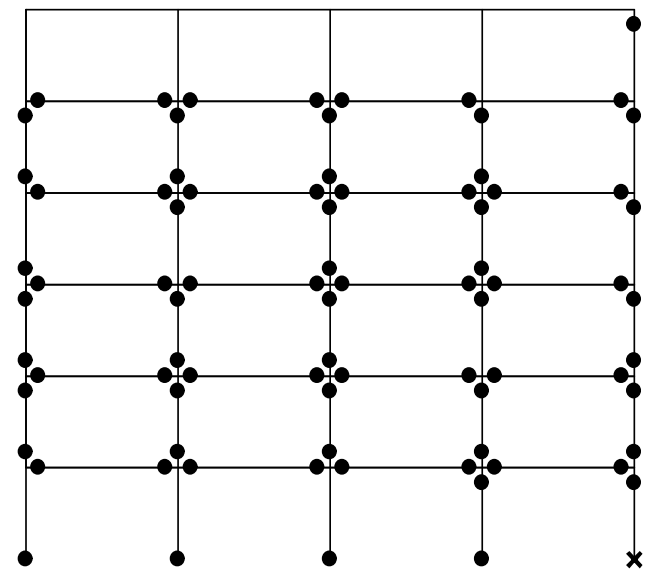

Imperial Valley $1.15 \mathrm{~g}$

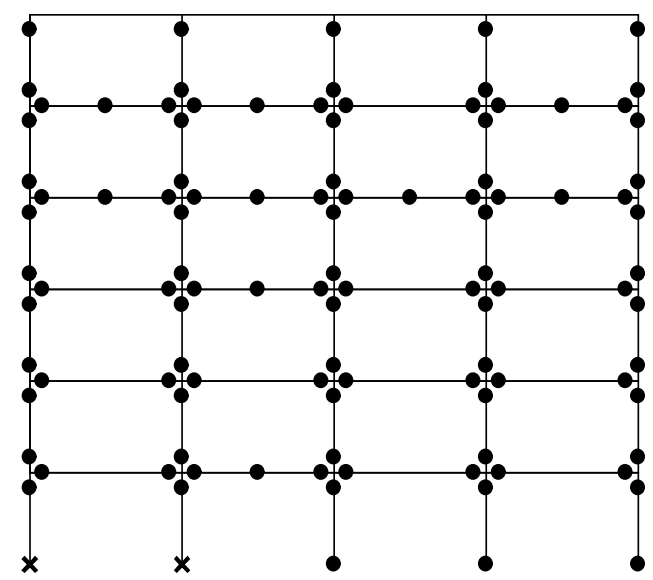

Sanfernando $8.15 \mathrm{~g}$

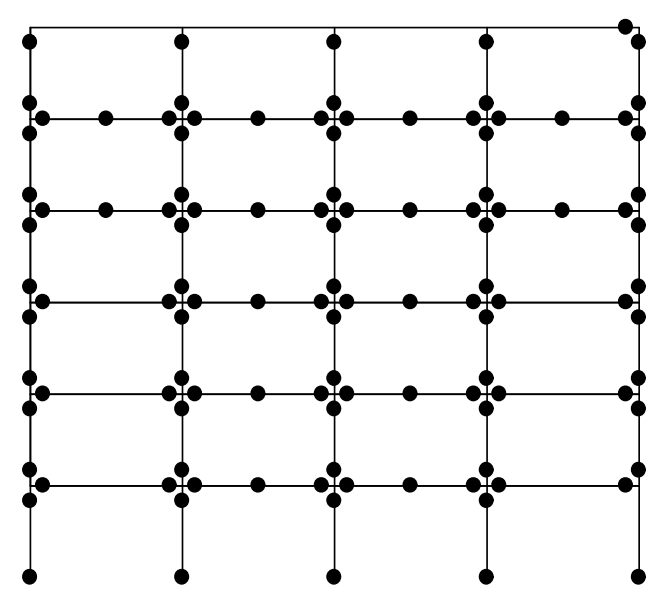

Loma Prieta 4.28g

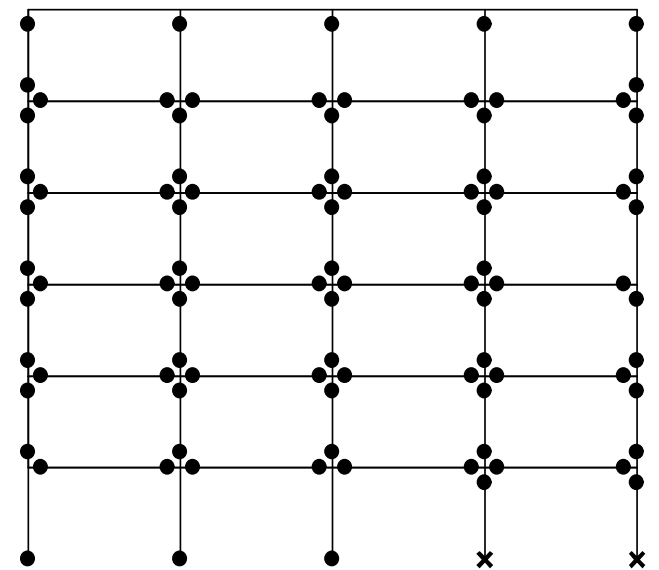

Northridge $2.60 \mathrm{~g}$

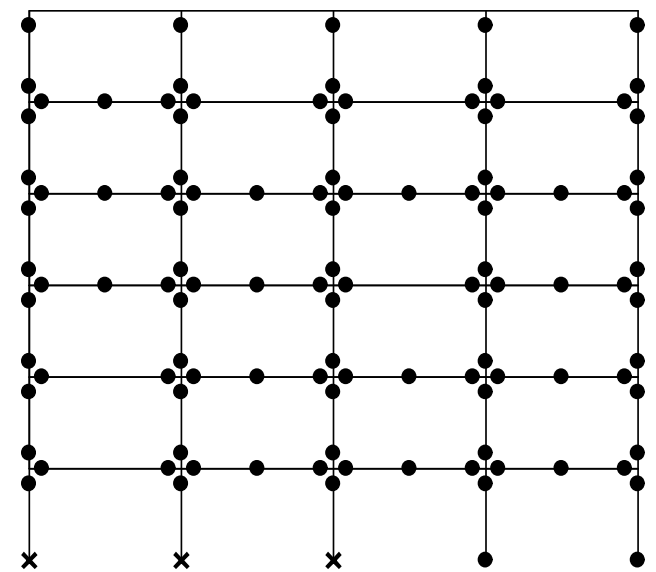

Whittier $5.00 \mathrm{~g}$

Figure 17: Damage scheme of Frame 8 using the horizontal seismic component 


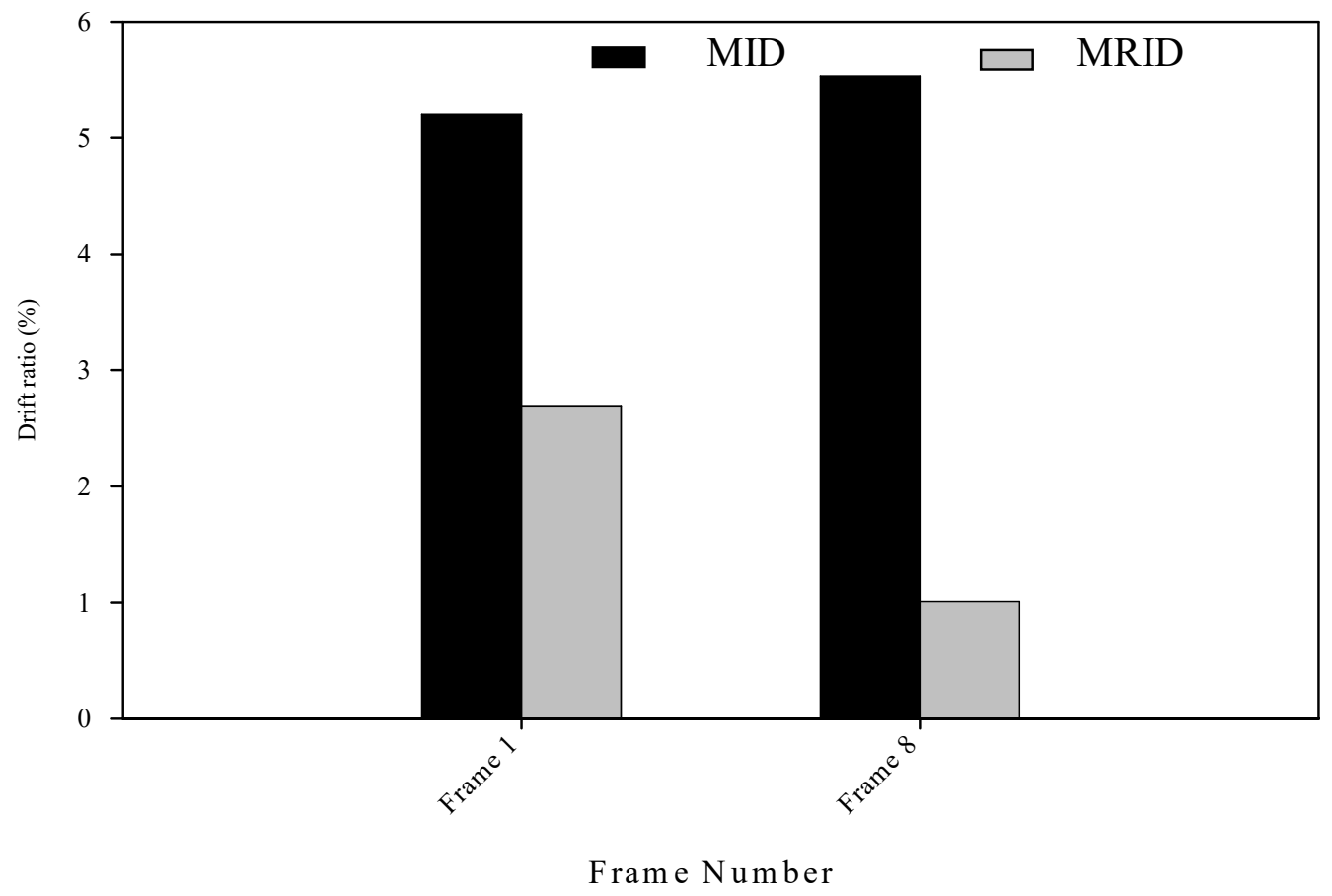

Figure 18: Average values of MID and MRID ratios for Frames 1 and 8 under the effect of the horizontal seismic components 